\title{
In search of beta
}

Article

Accepted Version

Creative Commons: Attribution-Noncommercial-No Derivative Works 4.0

Gregory, A., Hua, S. and Tharyan, R. (2018) In search of beta. The British Accounting Review, 50 (4). pp. 425-441. ISSN 0890-8389 doi: https://doi.org/10.1016/j.bar.2017.12.002 Available at https://centaur.reading.ac.uk/75035/

It is advisable to refer to the publisher's version if you intend to cite from the work. See Guidance on citing.

To link to this article DOI: http://dx.doi.org/10.1016/j.bar.2017.12.002

Publisher: Elsevier

All outputs in CentAUR are protected by Intellectual Property Rights law, including copyright law. Copyright and IPR is retained by the creators or other copyright holders. Terms and conditions for use of this material are defined in the End User Agreement.

\section{www.reading.ac.uk/centaur}

\section{CentAUR}

Central Archive at the University of Reading

Reading's research outputs online 


\title{
In search of beta
}

\author{
Alan Gregory, Shan Hua, Rajesh Tharyan \\ Emeritus Professor of Finance at University of Exeter, United Kingdom \\ University of Reading, United Kingdom \\ Xfi Centre, University of Exeter Business School, United Kingdom
}

\section{This version: Oct 2017}

\section{Keywords: CAPM, regulatory finance, beta}

Acknowledgements: The analysis in this paper results from a project funded by the Economic and Social Research Council (ES/J023914/1), and the authors would like to thank the ESRC for its support. In addition, the authors are grateful to Lucy Beverley (formerly of the UK Competition and Markets Authority and now with the Financial Conduct Authority) and Scott Sandles (Australian Energy Regulator) for their comments and their help in identifying key documents referred to in this paper. We would also like to thank participants at the 2016 BAFA Conference for their comments. Any errors and omissions are, of course, the authors' responsibility. 


\begin{abstract}
Despite its limitations, the CAPM is a popular asset pricing model. However, the estimation of beta in the CAPM is affected by the choice of the returns frequency and firm characteristics. This study undertakes a detailed examination of the evidence for the UK and we find that the differences in beta computed from returns of various frequencies are related to size, liquidity, book-to-market and to some degree, opacity factors. One area where our conclusions might have important implications is in the regulatory use of the CAPM. Our results imply that low frequency beta estimates should, in most cases, be preferred to high frequency beta estimates.
\end{abstract}

\title{
1. Introduction
}

Whilst the CAPM has been subject to considerable criticism (most recently by Dempsey [2013a], who catalogues the empirical failings of the model), the model retains a core role in modern finance.

Whether or not this is desirable is clearly debateable. One can argue, as in Dempsey (2013a, 2013b), Cai, Clatcher and Keasey (2013) and Moosa (2013) that it is time to move on to another paradigm altogether, or one can argue the case for an alternative factor model, such as the Fama-French model (Fama and French, 1993, 1996) or some form of conditional asset pricing model (Durack, Durand and Maller, 2004; Fletcher and Kihanda, 2005; Schrimpf, Schröder and Stehle, 2007). Alternatively, one can adopt the position of Brown and Walter (2013) and Smith and Walsh (2013) that the CAPM is defensible, and indeed according to the latter, despite being "half right" is "the only game in town". Whatever one's views on this, pragmatically it is hard to disagree with Partington (2013) who predicts that "the reign of the CAPM is unlikely to end anytime soon".

Discussions of the techniques of beta estimation, the suitability of alternative analogues for beta and the treatment of leverage in deriving asset betas are standard fare in both textbooks and regulatory reports. Early research also considered issues such as the effects of nonsynchronous trading (Dimson 1979, Scholes and Williams, 1977) and intertemporal parameter stability (Blume, 1971, 1975). In relation to the influence of the return frequency on beta estimation, an early work by Levhari and Levy (1977) showed that the impact on beta of lengthening the investment horizon (i.e. the return frequency) depends on the riskiness of stock. They find that the systematic risk $(\beta)$ of defensive stocks tends to decline while for aggressive stocks tends to increase with increases in investment horizon. Wood and McInish 
(1985) however, note that the results of Levhari and Levy (1977) are possibly affected by non-synchronous trading. Cohen et al. (1980) show that the effect of the decreasing of the return frequency may depend on the severity of thin trading problems. An added complication is the phenomenon known as "reference-day risk" (Acker and Duck, 2007). They find that, when using monthly returns, the choice of the reference day i.e. the particular day of the month and following month on the basis of which the monthly returns are calculated (difference in prices between those two days) affects estimates of the properties of monthly returns including the betas estimated from those returns. These effects exist for both individual stocks and market indices. They further note that the reference-day risk is a variant of sampling variation, albeit the effect of which had been previously underestimated.

Reinganum (1982) considers whether the size effect (Banz, 1981) is affected by the estimate of risk, and finds that that the size effect is driven by underestimated risk and that the effect is larger when the risk is estimated using returns measured over shorter intervals. Hawawini (1983) finds that betas estimated on the basis of daily, weekly or monthly returns vary substantially and in particular, that for firms with market values less than the average market value of all firms, the beta will decrease when the interval is shortened, while the opposite is observed for firms with market values greater than the average market value of all firms. Handa, Kothari, and Wasley (1989) specifically consider firm size and show that portfolio betas of small (large) market capitalisation firms rise (fall) as the return frequency is decreased.

As discussed above, much of the early literature that considered the effect of returns frequency on beta estimation has focussed on trading frictions and non-synchronous trading as potential explanations for the differences in betas estimated using different return intervals. Apart from a few exceptions, there appears to have been relatively less interest in investigating what firm-specific characteristics, apart from size and liquidity, might influence the way in which beta estimates vary with the frequency of their estimation. We add to this literature by considering how opacity (Gilbert et al., 2014), in addition to other firm characteristics such as size, leverage, $\mathrm{BE} / \mathrm{ME}$, illiquidity and industry affiliation are related to the betas estimated using different frequency returns.

Gilbert et al. (2014), show that estimates of beta are frequency-dependent, and that differences between high and low frequency betas can be explained by proxies for opacity of the firm. Opaqueness creates uncertainty about the effect of systematic news on the firm and 
this uncertainty affects how quickly such information is impounded into the prices. This, coupled with the risk averseness of investors, affects the returns of opaque firms at higher frequencies. At lower frequencies however, the effect of the systematic news is reflected in the returns of all firms (Gilbert et al., 2014). The consequence is that high frequency betas are particularly problematic in that they do not fully reflect risk characteristics. By contrast, low frequency betas will not suffer from this difficulty. Consequently, for opaque firms, using shorter return intervals results in a beta estimate that does not accurately reflect the riskiness of the stock. We add to the Gilbert et al. (2014) investigation in two ways. First, we consider whether other firm-specific risk factors such as gearing (leverage) and BE/ME apart from opacity, might make it more difficult to quickly interpret the impact of systematic news on the firm. Additionally, we consider whether these risk factors have explanatory power in the presence of controls for industry membership. Second, in addition to investigating the differences between high and low frequency betas, as in Gilbert et al. (2014), we also run the F-test of Gibbons, Ross, and Shanken (1989, hereafter GRS) in order to check whether or not the pricing errors from the CAPM at each beta frequency are jointly zero.

While the academic debate continues on the how best to estimate the parameters of the CAPM, in practice the CAPM is widely used. Evidence from surveys of practitioners, for example, Graham and Harvey, 2001; Brounen, De Jong and Koedijk, 2004: McLaney, Pointon and Tucker, 2004: Coleman, Maheswaran and Pinder, 2008), suggest that the CAPM is the preferred model for cost of equity computations. In relation to the regulatory use of the CAPM, in the UK, the CAPM is the only model currently accepted by the regulatory authorities. These include the Competition and Markets Authority (CMA), Ofcom, Ofwat, Ofgem and the CAA. ${ }^{1}$ The implication of this widespread use of the CAPM in the regulation of utilities is that fairly small variations in beta can have a very large economic impact when multiplied by the CAPM risk premium. For example, Buckland, Williams and Beecher (2015) cite an Ofwat report that "in the case of water, it has been estimated that a 0.5 percentage point variation in the cost of capital might translate into a change of $£ 10.00$ in the average annual bills of the 28 million households served by water companies in England and Wales (Ofwat, 2014: 2)." With a market risk premium of 5\%, such a variation is equivalent

\footnotetext{
${ }^{1}$ In the UK, monopoly utility services are subject to price regulation: telecommunications access prices are set by Ofcom, water and sewerage prices are set by Ofwat, electricity and gas network prices are set by Ofgem and monopoly airport landing charges are set by the CAA in conjunction with the CMA. The CMA has the role of being the appeals body for the regulated utility companies. Additionally, it has a key role in undertaking market investigations. For a full description see: https://www.gov.uk/government/organisations/competition-andmarkets-authority (last accessed 4th April 2016).
} 
to a change of only 0.1 in the estimate of the beta for a firm financed entirely by equity. Not surprisingly, regulated firms invest heavily in consultants and academics who argue the case for variations in the beta estimates, and regulatory bodies often employ others who argue for variations in the other direction. ${ }^{2}$ Consequently, research that objectively establishes how beta should be estimated has important policy implications and considerable economic impact. Whilst Gilbert et al. (2014) have analysed the position in the USA, given that in the UK regulators have expressed a preference for higher frequency returns over lower frequency returns in estimating betas, our study using UK data is potentially of added practical importance as it provides an out of (US)sample test. Additionally, we have a much longer run of data for the UK than for the other countries where Sudarsanam et al. (2011) show that the CAPM is the preferred model used by regulators.

The first objective of this paper is, therefore, to examine whether firm betas vary with the frequency of estimation in the UK. The second objective is to examine whether any differences in beta estimated using low versus high return frequencies can be explained. If they can be explained, and the explanatory variables can be construed as proxies for omitted systematic risk variables, then the implication is that some frequency estimates may be understating the true beta. The third objective is to examine the evidence on whether beta estimation frequency has an impact on asset pricing tests of the CAPM.

Consistent with previous evidence, we find that there are systematic differences in betas estimated from low versus high frequency returns. Additionally, we find that the differences in beta estimates from using returns of various frequencies are related to size, illiquidity, opacity and industry affiliation in general, but there are some variations across size and illiquidity subsamples. We show that for all but the largest group of companies, lower frequency beta estimates are preferable to higher frequency estimates. For the largest group of companies, the evidence suggests that either one could be used. We also provide limited but corroborative evidence through a time series asset pricing test of the CAPM that lower frequency estimates are preferable to higher frequency estimates.

\footnotetext{
${ }^{2}$ Note that in the UK, cost of capital is an important parameter in market investigations. The UK's approach to such investigations differs from that in many other countries. See, for example, the UK and Australian positions set out in the OECD paper on excessive prices: http://www.oecd.org/competition/abuse/49604207.pdf (last accessed 4th April 2016).
} 


\section{Data and Methodology}

\subsection{Data}

To construct our sample, we deliberately exclude small firms for three reasons. First, it is well-known that smaller stocks suffer from thin trading problems (Dimson, 1979). Including such stocks in our test portfolios would effectively be loading the experiment in favour of finding that high frequency betas are problematic. To avoid this problem, we limit our portfolios to the top $30 \%$ of firms by market capitalisation. Secondly, in pragmatic terms, the regulators discussed above are typically concerned with larger firms rather than smaller ones. To the extent that small firms are regulated, they are typically subsidiaries of larger firms ${ }^{3}$. Finally, we know that asset pricing models for the UK perform more successfully when limited to larger firms (Gregory, Tharyan and Christidis, 2013) and that pricing small value stocks in particular is a general challenge for asset pricing models (Fama and French, 2012).

All our estimates use the longest data period available. Our major restriction is the availability of returns data on The London Share Price Database (LSPD) daily database. To run our regressions, we need a sufficient run of data to estimate monthly betas ${ }^{4}$ using five years' of returns data from the monthly LSPD, 250 trading days of data to estimate daily beta, and 104 weeks to estimate the weekly betas. Additionally, we need lagged values of our opacity measure (which are formed using the accounting data described below), market capitalisation, liquidity, book equity to market equity and gearing/leverage. The Gilbert et al. (2014) measure of opacity (based on the Jones 1991 model) can only be measured at annual intervals, so that the only betas we run regressions for are those calculated six months after the financial year end.

These requirements mean that our first regression to explain the difference between monthly, weekly and daily beta estimates can be run in 1988, and the final regression in 2013. The month within the year that we start is affected by the availability of accounting data needed to estimate our measure of opacity (which is based on the Jones 1991 model) and the way we form our book-to-market portfolios for the GRS test portfolios. Following Fama and French (1996), it has become standard practice to allow at least 6 months between the financial year end (FYE) and the portfolio formation date. Because of the prevalence of March year

\footnotetext{
${ }^{3}$ For example, in the 2010 Bristol Water appeal case to the UK's Competition Commission, although the appellant was a small firm, and treated as such by the CC, it was actually a subsidiary of a large multi-national. ${ }^{4}$ In unreported results, we also estimate quarterly betas using ten years' of returns data from the monthly LSPD files. These results are available from the authors on request.
} 
financial year ends in the UK, we follow Gregory et al. (2013) and use end-September portfolio formation dates for UK firms.

In order to maintain the inter-temporal consistency of the beta estimates, our monthly betas use 60 months of data, ending in September, whilst our weekly beta estimates use 104 weeks of data ending on the 40th week, and the daily estimates use 250 trading days of data ending in the same week, which we refer to as the Conventional Estimation Period results, the terminology coming from the approaches typically used by regulators and academic researchers. ${ }^{5}$ These calculations are then repeated each year such that we have estimates of monthly, weekly and daily betas for the period 1988-2013 for the UK. If any observations are missing such that a beta cannot be estimated for a particular date-frequency, we drop that firm-date observation from the sample for all frequencies.

We also compute the monthly, weekly and daily betas over a common five year horizon, which we refer to as the Common Estimation Period results. Although this is not normally done in regulation, as one of the arguments regulators use to justify high frequency estimation is "up to datedness", examining such betas may help in determining whether any differences are due to estimation frequency in its strictest sense.

Our market returns is the total return on the FT All-Share Index and the risk-free rate of return is the 3-month Treasury Bill Rate. The firm returns are from LSPD and firm level accounting variables are from Datastream.

\subsection{Beta Estimation}

We estimate betas by running OLS, time series regressions of the form:

$$
R_{i t}-R_{f t}=\alpha_{i}+\beta_{i}\left(R_{m t}-R_{f t}\right)+\varepsilon_{i t}
$$

Where $R_{i t}$ is the return on the stock i for period t, $R_{f t}$ is the risk-free rate, and $R_{m t}$ is the return on the market portfolio. To avoid outliers unduly influencing the regression tests for differences in beta, we drop any observations where the differences between the high and low frequency betas are in the extreme percentiles of the distribution.

\subsection{Liquidity Measures}

\footnotetext{
${ }^{5}$ Though of course we concede that other estimation periods can be used and are equally valid.
} 
For liquidity we consider three measures. The first is the Amihud illiquidity ratio, $A_{i t}$ (scaled by one million), from Amihud (2002), calculated over the prior year ending September. We Winsorise this measure at the $1 \%$ level. This measure captures the average daily price response associated with one currency unit of trading volume and is defined as:

$$
A_{i t}=\frac{1}{D_{t}} \sum \frac{\left|R_{i d t}\right|}{V O L_{i d t}}
$$

Where $R_{i d t}$ is the return on stock $\mathrm{i}$ for day d of year $\mathrm{t}, V O L_{i d t}$ is the daily volume in the local currency unit on stock i for day $d$ of year $t$ and $D_{t}$ is the total number of trading days in year $t$. However, there is a problem with this measure of illiquidity as the return to volume ratio (the summed term on the RHS) is inevitably influenced by the size of the firm. It further ignores the frequency of trading. These limitations motivate Florackis, Gregoriou and Kostakis (2011) to develop an alternative measure, based on what they term a "return to turnover ratio", $T R_{i d t}$, defined as the stock's daily trading volume divided by the number of shares outstanding. Formally, the measure is:

$$
R_{-} t o_{-} T R_{i t}=\frac{1}{D_{t}} \sum \frac{\left|R_{i d t}\right|}{T R_{i d t}}
$$

We use $R \_t o \_T R$ as our main measure of illiquidity. Florackis et al. (2011) show this measure to be free of size bias in the UK and we also find that it has a lower correlation with size in our data. Additionally, we find it has better explanatory power in our regression tests. Nonetheless, in unreported robustness checks ${ }^{6}$, we obtain broadly similar conclusions when the Amihud measure is used. Finally, following Gilbert et al. (2014) we investigated a third measure of liquidity, the trading volume per year per share outstanding (turnover), which, in common with the $R \_t o \_T R$ measure, we Winsorised at the $1 \%$ level. As we find we get lower R-squareds in regressions using this measure of liquidity, we treat it as a robustness check only and do not report results using this measure. Our key results are unaffected by the use of this measure in place of $R \_t o \_T R$ and similarly are unaffected by including both measures simultaneously, despite the obvious (negative) correlation between the measures.

\subsection{Opacity Measure}

Our proxy for opacity is a measure based on discretionary (abnormal) accruals computed using a modified Jones (1991) model. This measure reflects accruals management and works as a good proxy for firm opacity. As Bradshaw, Hutton, Marcus and Tehranian (2009 p.69) notes "Considerable evidence indicates that accruals management obscures at least some

\footnotetext{
${ }^{6}$ Available from the authors on request
} 
information about firm fundamentals (see, e.g., Sloan, 1996) and is thus a direct, firmspecific measure of opacity. In addition, aggressive earnings management is likely to proxy for management's general proclivity to hide information from the capital market and thus captures less easily quantifiable or observable aspects of opacity”.

The model that we use follows Mouselli, Jaafar and Goddard (2013) and our specific measure of opacity is the absolute value of abnormal accruals, which is the absolute value of the discretionary component of total current accruals. The total current accrual for each firm $T C A_{i t}$ is defined as

$$
T C A_{i t}=\left(\Delta C A_{i t}-\Delta C a s h_{i t}\right)-\left(\Delta C L_{i t}-\Delta S T D_{i t}\right)
$$

Where, $\Delta C A_{i t}$ is the change in current assets, $\Delta$ Cash $_{i t}$ is the change in cash and short-term investment, $\Delta \mathrm{CL}_{\mathrm{it}}$ is the change in current liabilities and $\Delta \mathrm{STD}_{\mathrm{it}}$ is the change in short-term debt.

We then run a cross-sectional OLS regression across all the firms in each industry for each year with the following specification and obtain industry year specific estimates of $\alpha_{1}$ and $\alpha_{2}$.

$$
\left(\frac{T C A_{i t}}{T A_{i t-1}}\right)=\alpha_{1}\left(\frac{1}{T A_{i t-1}}\right)+\alpha_{2}\left(\frac{\Delta R E V_{i t}}{T A_{i t-1}}\right)+\varepsilon_{i t}
$$

where, $\mathrm{TA}_{\mathrm{it}-1}$ is lagged total assets, $\Delta \mathrm{REV}_{\mathrm{it}}$ is the change in revenue.

Since this approach estimates an annual cross-sectional industry level model, it has the advantage of avoiding survivorship bias and also allows for variations through the business cycle. ${ }^{7}$ Further, applying the model at an industry level avoids the considerable loss of power associated with applying the model at a firm level (Dechow et al., 2012, p.290). In order to ensure we have sufficient firms in each industry sector, we start with Datastream Level 3 industry classifications (19 industries) but in some cases have to combine industries to give enough observations in each sector. Precise details are set out in the Appendix (Table A1). Since BE/ME and non-discretionary accruals have an ambiguous meaning for some industries, as is standard in the literature, we drop financials and real estate from our analysis. Specifically, as we show in the appendix Table A1, we drop Insurance, Financial Services, Banks and Real Estate. We merge Automobiles and Parts into Personal and Household Goods, leaving 14 industry groupings in total.

\footnotetext{
${ }^{7}$ Unfortunately, there is no guidance in Gilbert et al. (2014) on exactly how the Jones (1991) model is operationalised in their paper.
} 
Using the estimates of $\alpha_{1}$ and $\alpha_{2}$, for each firm the non-discretionary part of its total current accruals, $N D A C_{i t}$, is calculated as

$$
N D A C_{i t}=\hat{\alpha}_{1}\left(\frac{1}{T A_{i t-1}}\right)+\hat{\alpha}_{2}\left(\frac{\Delta R E V_{i t}-\Delta A R_{i t}}{T A_{i t-1}}\right)
$$

Where, apart from the variables as defined earlier, $\Delta \mathrm{AR}_{\mathrm{it}}$ is the change in accounts receivable. The absolute value of discretionary (abnormal) accrual is then calculated as the absolute value of the remaining portion of the total current accruals $(A A A)^{8}$.

$$
\left|D A C_{i t}\right|=\left|\left(\frac{T C A_{i t}}{T A_{i t-1}}\right)-N D A C_{i t}\right|
$$

Finally, to avoid undue influence from outliers we Winsorise this at the $1 \%$ level.

Gilbert et al. (2014) also uses an alternative measure of opacity which comes from the questionnaire based research of Hambrick and Abrahamson (1995). As Gilbert et al. (2014) describe the process, the questionnaire "focuses on managerial discretion at the industry level between 1985 and 1989 for 31 industries as defined by two-digit SIC codes. We assign the managerial discretion measure to all firms in our sample between 1969 and 2010, based on the firm's two-digit SIC code. All firms in the same industry therefore receive the same score." We do not directly use this measure as there are several issues with applying this measure for our purposes. The first is that the 31 industries surveyed do not constitute a comprehensive sample, so that some industries simply have no data. The second is that these 31 industries do not map neatly on to the Datastream industry level categories that we can observe. For these reasons, as an alternative, we use DS Level 3 industry dummy variables (modified as described above) in our analysis. ${ }^{9}$

\subsection{Size, Leverage and Book to Market measures}

\footnotetext{
${ }^{8}$ In unreported robustness tests, we ran our regressions using the variance of the discretionary accruals over the prior three years rather than the lagged value itself. The results of doing so were qualitatively similar to those reported. Gilbert et al. (2014) note that the variance of abnormal accruals makes the firm's production function more difficult to discern and therefore investors require more information and time to price the impact of news, and this leads to higher opacity.

${ }^{9}$ In an ideal world, we would, of course, like to examine the case of regulated firms in particular. However, our estimation of the opacity measure requires us to form portfolios of firms based on these Datastream industry level categories.
} 
Size: In order to avoid time trends due to increases in market capitalisation, we use the market capitalisation of the firm as a percentage of the total capitalisation of the market in each year in our analysis. This variable (Size) is lagged by one year.

Leverage or gearing: This we measure as total debt to market value of equity (TD/ME). Our prior would be that indebted firms may be more complex. For example, Manconi and Massa (2009) suggest that firms characterised by higher complexity tend to fund their financial deficit with more debt and less equity. So if leverage has such an impact, we might expect a positive association between leverage and the difference between low frequency and high frequency estimates.

Book-to-market ratio: We measure Book-to-market ratio as the ratio of Book equity to Market Equity (BE/ME). There are several plausible reasons why there could be an association between BE/ME and beta. Pope and Stark (1999) provide a model, based upon real option theory and costly reversibility, which shows that the CAPM beta will be a function of the BE/ME ratio. In a similar vein, Zhang's (2005) model of costly reversibility combined with a counter-cyclical costs of risk proposes that value firms are riskier than growth firms. However, in both cases the influence on the difference between high and low frequency betas is indeterminate. On the one hand both models posit a dynamic cost of capital. $^{10}$ On the other hand, in the spirit of Gilbert et al. (2014), the implied greater complexity of firm structure in such a model may lead to firms with complex real options being more "opaque". In a CAPM world the corollary would be that beta should be associated with BE/ME. Finally, Campbell, Polk and Voulteenaho (2010) provide a useful review of CAPM beta decomposition. "Value" stocks (i.e. those with high BE/ME) have a higher sensitivity to so-called "bad" beta, which captures cash flow shocks. The implication is that $\mathrm{BE} / \mathrm{ME}$ captures an important risk exposure. Whilst the common theme here is that $\mathrm{BE} / \mathrm{ME}$ is a proxy for risk, if that risk is particularly difficult to interpret we might expect a positive association between $\mathrm{BE} / \mathrm{ME}$ and the difference between low frequency and high frequency estimates. ${ }^{11}$

\footnotetext{
${ }^{10}$ We are grateful to Andy Stark for this point.

${ }^{11}$ One interesting possibility would be to consider R\&D/ME as a proxy for complexity. For example, Al Horani, Pope and Stark (2003) show that R\&D may be a priced risk factor in the UK. However, R\&D is only reported in the UK for accounting periods starting on or after $1^{\text {st }}$ January 1989 (under SSAP13), so allowing for accounting lags, this would mean that September 1991 would be the first period for which we could obtain estimates of R\&D/ME. In addition, for many firms reported R\&D is not present on Datastream.
} 


\section{Results}

\subsection{Descriptive statistics}

We start with an analysis of betas computed using returns of different frequencies in Table 1. In Panel A, we report the betas before dropping extreme observations (defined using the highest and lowest percentile differences between monthly and daily and monthly and weekly betas) and in Panel B we report the betas after dropping these extreme observations. In both Panels, using conventional estimation periods we note that the mean $\beta_{\mathrm{EW}}$ decreases markedly as we move from low frequency (monthly) to higher frequency (weekly and daily) intervals. Although the mean $\beta_{\mathrm{Vw}}$ does not show this monotonic decrease in Panel A, once we drop the extreme percentile observations, the Monthly value weighted (VW) betas are larger than both the Weekly and Daily betas and are also closer to unity.

We see similar results when we estimate the betas using a common estimation period. We also conduct tests for significant difference in the mean monthly $\beta_{\mathrm{Vw}}$ versus the mean weekly $\beta_{\mathrm{Vw}}$ and the mean daily $\beta_{\mathrm{Vw}}$, after dropping extreme observations. For the conventional estimation period we find that the difference between monthly and weekly and monthly and daily betas are statistically significant and that all the mean $\beta_{\mathrm{Vw}}$ are statistically significantly different from unity. We find similar results for the common estimation period. In both cases, however the monthly mean $\beta_{\mathrm{Vw}} \mathrm{S}$ are closer in magnitude to unity. However, it is worth noting here that because we drop financials and real estate, both of which tend to be high beta industries $^{12}$, we cannot assume that the mean $\beta_{\mathrm{Vw}}$ should be unity.

Table 2 and Table 3 reports the summary statistics for the size, liquidity and opacity proxies together with beta differences, gearing (TD/ME) and book to market (BE/ME) variables for the monthly vs weekly and monthly vs daily data respectively. Panel A reports summary statistics whilst Panel B shows the correlations between variables. In Tables 2 and 3, consistent with $R \_t o \_T R$ being a measure of illiquidity (i.e. as opposed to liquidity) it is negatively correlated with size ${ }^{13}$. Rather more strikingly, beta differences in both the tables are inversely correlated with size and positively correlated with illiquidity. Across Tables 2 and 3, the largest (absolute values) correlations between the difference in beta and other variables, is for size ( 0.29 and 0.22 for the conventional estimation periods and 0.33 and 0.24

\footnotetext{
${ }^{12}$ See, for example, recent LBS Risk Measurement Service Quarterly publications.

${ }^{13}$ In unreported figures, we find that consistent with the evidence in Florakis et al. (2011), in all cases the correlation between the Amihud and $R \_t o \_T R$ measures of illiquidity are reasonably strong.
} 
for the common estimation period). Thus size has strong explanatory power for the difference in betas. We conduct further analysis on the effect of size and the results are reported in Tables 9 and 10 .

\subsection{Regression results}

To explain the difference in the beta estimates, we run the following regression for each of the monthly-weekly and monthly-daily beta difference specifications:

$$
\begin{gathered}
\Delta \beta_{i t}=a+b . A A A_{i t-1}+c . S_{i z e_{i t-1}}+d_{.} R_{-} t o_{-} T R_{i t-1}+e .(B E / M E)_{i t-1} \\
+f .(T D / M E)_{i t-1}+\sum i . I N D_{i}+\epsilon_{i t}
\end{gathered}
$$

Where in addition to the variables described earlier, $\Delta \beta$ is the difference between monthly and weekly betas or monthly and daily betas, and $I N D_{i}$ is an industry dummy (see Appendix Table A1 for a detailed description). When industry dummies are included, we run the regressions without the constant, so the coefficients on the each of the dummy variables reflects its effect on $\Delta \beta_{i t}$. All standard errors, clustered by firm and year, are estimated using the two-way cluster robust standard error (or CL-2) approach of Petersen (2009), which Gow et al. (2010) show to yield well-specified standard errors in accounting panel data simulations.

Table 4 presents the results from the regression of monthly betas minus daily betas on the variables of interest. The first two columns report the results for the conventional estimation period while the last two columns report the results using the common estimation period. "Full 1(3)" refers to the model described by (8) above without industry dummies, but with an intercept, whilst "Full 2(4)" refers to the model described by (8) with industry dummies but without an intercept.

For the conventional estimation period, opacity is only weakly significant in the absence of industry dummies, and loses its significance when industry dummies are introduced. However, Size, illiquidity (R_to_TR) and BE/ME are consistently significant in explaining beta differences. This result is consistent with $\mathrm{BE} / \mathrm{ME}$ capturing information about real options that markets need time to interpret Adjusted R-squareds show significant improvement with the inclusion of industry dummies, which demonstrates explanatory power of industry effects for the difference in betas. 
When we run the regressions using a common estimation period, in line with the findings of Gilbert et al. (2014) we find that opacity explains the difference in betas. This is consistent with the conjecture that markets need more time to fully interpret new information for more "opaque" companies than less opaque ones. The last column of Table 4 shows that this effect is robust to the inclusion of industry dummies. Overall, as might be expected, and consistent with the Table 1 evidence on the difference between mean beta and value-weighted mean beta, size effects have an important role to play, in so far as larger companies show less difference between monthly and daily betas than smaller ones, and the less liquid a firm's stock is, the greater the difference between monthly and daily betas. For gearing, there are no significant effects, but the $\mathrm{BE} / \mathrm{ME}$ is associated with beta differences for the conventional estimation period and is also weakly significant for the common estimation period when industry dummies are included.

Table 5 presents the results from the regression of monthly betas minus weekly betas on the variables of interest. Similar to the results in table 4, size and illiquidity are robustly associated with the difference in betas across both conventional and common estimation periods. Opacity continues to be significant only when we use a common estimation period. We also note that significant explanatory power of industry effects as in table 4.

Taken together, the evidence from tables 4 and 5 suggest that there are differences in betas, arising from estimation frequency that are related to size, liquidity and industry factors, and less robustly to opacity and BE/ME. These results, together with the observation from Table 1 , Panel B that both $\beta_{\mathrm{VW}}$ and $\beta_{\mathrm{EW}}$ estimated using higher frequency returns are underestimated, implies that higher frequency betas (weekly and daily betas) may not be as reliable indicators of the true beta as lower frequency betas (monthly). That we are able to explain the differences between high and low frequency betas by factors that can be viewed as proxies for risk suggests that the high frequency beta estimates omit important risk characteristics.

In Table 6, we report industry coefficients for the Full 2 and Full 4 models, presented in tables 4 and 5. We note that, except for utilities, all the industries have a significant positive coefficient. The coefficient on utilities is positive though not statistically significant. It is perhaps worth pausing to consider what this means, and, more importantly, what it does not mean. It does not mean that for utilities the difference between high frequency and low frequency betas is unimportant. Rather, it means that beyond those variables that can explain 
the difference (broadly, size, illiquidity, opacity and BE/ME), simple industry membership has nothing further to add. In all other cases, it does. This suggests that some industries are particularly difficult to understand in terms of the impact of changes in systematic risk factors, and that there are other factors at work in addition to our chosen measures. Alternatively, one could interpret this result as suggesting that our chosen opacity measure is a poor measure of true opacity in most industries.

In Tables 7 and 8 we carry out further analysis by running regressions similar to (8), but we now run regressions on subsamples partitioned on the basis of size and illiquidity. In Table 7 , which presents the monthly versus daily analysis, we find that even for the largest and most liquid of companies, size and illiquidity measures are significantly associated with the difference in betas. Not surprisingly the significance of the illiquidity factor diminishes when we consider the most liquid companies, but the effect is still significant at $10 \%$. Industry effects continue to be important. Opacity is significant only when we use common estimation periods. BE/ME is not robustly associated with the difference in betas in these partitioned samples. In Table 8 (monthly versus weekly), we find broadly similar results, with size and illiquidity continuing to be significantly associated with the difference in betas. However, $\mathrm{BE} / \mathrm{ME}$ is now consistently associated with beta differences in the conventional estimation period results. The results from tables 7 and 8 , together with the evidence from Table 1. Panel B, suggests that high frequency beta estimates may omit important risk characteristics even in the case of larger and more liquid firms.

In Tables 9 and 10, we carry out further tests on the role of size. From the regressions, it is evident that there is an inverse relationship between size and the difference in betas. In Tables 9 and 10, we form size quintiles and examine the summary statistics of the variables of interest across the size groups. For the largest firms, it is noteworthy that the average relative size is at least five times greater than the average relative size of the next lowest size group. We also note that not surprisingly the illiquidity falls as we move from the smallest to the largest group. Importantly, we find that consistent with the evidence from the regressions, the average difference in betas decreases as we move from the smallest to the largest portfolio of firms. The difference in beta is significantly different from zero at $1 \%$ level for all but the largest portfolio. This is true for both the difference in monthly and weekly betas and monthly and daily betas and across both conventional and common estimation periods. 
For the largest portfolio, the difference is still positive (i.e. the low frequency beta is greater than the high frequency beta) but statistically insignificant.

The evidence so far suggested that low frequency betas estimates may be underestimated. Our additional analysis in Tables 7-10 provides additional support for this finding, although Tables 9 and 10 suggest that the relationship is weak for the largest group of companies.

\subsection{GRS Test Results}

Our final set of tests involves standard GRS tests of the CAPM ${ }^{14}$. The GRS F-statistic tests whether the time-series intercepts (pricing errors) are all zero when excess returns on assets under consideration are regressed against the risk factors of any particular asset pricing model. With $\mathrm{N}$ number of test assets, the test is whether the $\mathrm{N}$ intercepts are jointly indistinguishable from zero. In testing the CAPM, the GRS test proceeds by running OLS time series regressions of the form

$$
R_{i t}-R_{f t}=\alpha_{i}+\beta_{i}\left(R_{m t}-R_{f t}\right)+\varepsilon_{i t}
$$

for each test asset portfolio. $R_{i t}$ is the return on the test portfolio, $R_{f t}$ is the risk-free rate, $R_{m t}$ is the return on the market portfolio. The form of the test is

$$
T\left[1+\left(\frac{E_{T}(f)}{\hat{\sigma}(f)}\right)^{2}\right]^{-1} \hat{\alpha}^{\prime} \hat{\Sigma}^{-1} \widehat{\alpha} \sim \chi_{N}^{2}
$$

Where $E_{T}(f)$ denotes the sample mean of the factor, $\hat{\sigma}(f)$ denotes the sample variance and $\widehat{\alpha}$ is a vector of estimated intercepts. $\hat{\Sigma}$ is the residual covariance matrix and $\mathrm{T}$ is the number of time periods. The GRS test statistic is then

$$
\frac{T-N-1}{N}\left[1+\left(\frac{E_{T}(f)}{\hat{\sigma}(f)}\right)^{2}\right]^{-1} \hat{\alpha}^{\prime} \hat{\Sigma}^{-1} \widehat{\propto} \sim F_{N, T-N-1}
$$

If there is a "missing risk" component in high frequency betas, this should show up in up to three ways. First, GRS tests of the CAPM should be less anomalous when we use low frequency betas rather than high frequency betas. Second, the explanatory power of the regressions (as measured by the mean R-squared of the portfolio regression tests) should be higher for low frequency betas compared to high frequency betas. Third, individual portfolio alphas should be less significant for low frequency estimates than for high frequency ones.

\footnotetext{
${ }^{14}$ GRS test (a time series regression test) is a standard test of the joint significance of the alphas in the asset pricing literature, although widely used, we note that increasing the number of test assets $(\mathrm{N})$, relative to the number of time series (T) will have an adverse effect on the power of the test. However, we do not see this as a problem for the number of test assets and length of the time series we consider.
} 
In conducting these tests, we report two sets of results. The first uses the "standard" FamaFrench value-weighted portfolios formed using the intersection of size (market capitalisation) and book-to-market. These portfolios are formed from the top 30\% of firms by market capitalisation each year. Every year (in September) we take this sample of top 30\% of the firms and we independently sort these into three book to market groups by using the $30^{\text {th }}$ and $70^{\text {th }}$ percentile of the BE/ME) (or book to market) ratio and quintiles by size. The intersection results in fifteen size and book-to-market portfolios. The second set of tests, following the suggestion of Lewellen et al. (2010, p.182), uses value-weighted portfolios formed on the basis of volatility (the standard deviation of returns). Similar to the formation of the size and book-to-market portfolios, using the sample of the top 30\% of firms by market capitalisation, every year we sort firms into twelve size groups based on the standard deviation of returns over the previous 12 months.

The results based on the size and book-to-market sorts (Table 11) suggest that the CAPM in does surprisingly well in terms of the GRS tests. ${ }^{15}$ When tested against the size and book to market portfolios (Table 11) we cannot reject the hypothesis that all the intercepts are jointly insignificant for any of the beta frequency estimates. None of the alphas is significant. Nonetheless, we observe that the mean R-squared falls monotonically as we move from monthly through to daily betas. Allowing for differences in return periods, there is also a tendency for intercepts to be closer to zero when low frequency betas are used. ${ }^{16}$ The annualised intercepts ${ }^{17}$ show a tendency to increase as we move from monthly to daily data. However, a very different picture emerges when test portfolios are formed on the basis of the standard deviation (Table 12). Whilst we cannot reject the joint significance of the intercepts for any of the frequency estimates, we see evidence that some individual portfolios have significant alphas, and that this propensity increases with the frequency of estimation. When betas are estimated monthly, one intercept (the low volatility portfolio) has an alpha that is significantly positive at the $5 \%$ level, with a further one being significant at the $10 \%$ level. Once we move to weekly and daily frequencies, we observe that two alphas are significant at

\footnotetext{
15 This is likely to be attributable to the restriction of the model to larger firms - see Gregory, Tharyan and Christidis (2013), and also Fletcher (2010) for a rather more pessimistic analysis of UK asset pricing. Additionally, in unreported tests using Fama-MacBeth regressions we find that the market risk factor is never priced.

${ }^{16}$ Note that the mean alphas reported in the table are monthly, weekly and daily returns respectively so cannot be compared without multiplication. Hence our reporting of annualised returns.

${ }^{17}$ Annualised intercepts are $(1+\mathrm{r})^{\mathrm{n}}-1$, where $r$ is the unrounded intercept and $n$ is the number of compounding periods per annum (i.e. 12 for monthly, 52 for weekly and 250 for daily).
} 
the $5 \%$ level, with a further one being significant at the $10 \%$ level. Further, these portfolios are at the extremes, with the low volatility portfolios exhibiting significant positive alphas but the high volatility portfolios exhibiting significant negative alphas. When tests are carried out on this basis, the annualised intercept mean return is actually lowest on a monthly basis ( $0.11 \%$ p.a.), but highest on a daily basis $(1.20 \%)$. Taken as a whole, these results, whilst not compelling, hint that the CAPM may be better specified as a risk pricing model when betas are calculated on a low frequency basis.

\section{Conclusion}

Whatever views one might have on the suitability of the CAPM, the model is used extensively by practitioners and regulatory authorities around the world. How to estimate beta in applications that use the CAPM is therefore an important issue. As we have noted, there has been a tendency for UK regulatory bodies to regard high frequency beta estimates as more useful, and indeed in some cases judgements have been made that daily betas are superior to monthly betas. The research question that this paper has addressed is whether there is any validity in the use of high frequency betas. We already know, from Gilbert et al. (2014), that high frequency betas are problematic in the US, and so the focus in this paper has been on assessing whether beta estimates are frequency dependent in the UK, and if so whether these differences can be explained by variables that may be plausibly construed as risk factors.

We have shown that high frequency betas generally have lower mean values than low frequency (monthly) betas. We then investigated if these differences can be explained. We have shown that these differences can be explained by size, illiquidity and industry effects and, to some degree, by market to book effects and opacity. These results all apply in our full sample, which by design eliminate the smallest firms in order to avoid known thin trading problems. This decision was also motivated by us noting that typically only larger firms are subject to regulation or market investigations. Nonetheless, in robustness tests we showed that most of these effects remain even when we run tests on sub-samples of the largest stocks and most liquid stocks. The evidence that high frequency betas may be underestimated together with the evidence that we are able to explain the difference using variables that might proxy for risk suggest that in general high frequency beta estimates do not fully reflect the likely risk characteristics of stocks. Therefore their use in the CAPM, in preference to a low frequency beta estimates, is likely to under-estimate the cost of equity capital, on 
average. We also showed that there is some corroborating, albeit weak, evidence that intercepts from CAPM portfolio regression tests are somewhat more likely to be significant when high frequency betas are employed, and that the mean R-squareds from these portfolio tests tend to be inversely related to beta frequency. These results are consistent with low frequency betas giving better estimates of the true beta.

Our findings have potential policy implications for regulators and other users of the CAPM. In general, low frequency betas should be preferred to high frequency betas. If users still wish to use high frequency betas in their analysis, then it is important to check whether those high frequency beta estimates are being biased downwards by size, illiquidity and industry effects and to a lesser extent opacity and BE/ME. That said, clearly these issues, whilst important, are of even greater significance when looking at smaller and medium sized firms.

However, we note an important caveat with respect to our study. Our estimates of beta could potentially be affected by reference day risk (Acker and Duck, 2007). Acker and Duck (2007) use Datastream return indices and find that reference day risk affects the estimation of betas. In using the monthly LSPD database for our monthly beta estimates we are confined to using the LSPD's own reference days, which are trading month ends. Furthermore, by design our study uses a common reference day each year $\left(30^{\text {th }}\right.$ September) to allow for the fact that annual report and accounts information needs to become embedded in stock prices. This date is common to each of the estimates of monthly, weekly and daily data.

Given that our primary focus is on explaining the differences in betas with firm characteristics that might plausibly proxy for risk, our assumption is effectively that any reference day risk will have a similar impact on each of these estimates and so will not affect inferences about the differences between betas using different frequencies. This assumption would seem to be reasonable in the case of the common estimation period analysis, though is clearly more questionable when we look at the conventional estimation period results, where the starting reference day (though clearly not the terminating reference day) differs according to beta frequency. Furthermore, noting the Acker and Duck (2007) findings with relation to portfolio betas, we note that our size portfolio results in Tables 9 and 10 still show marked differences in betas estimated from different frequencies. Nonetheless, an interesting question for future research is whether the same effects exist if LSPD daily returns data are used in reference day comparisons. It is also worth noting that the large difference in the size of the effect for telecoms versus utilities could be further explored in future research. 
In conclusion, our findings suggest that on average, a cost of equity estimated from a CAPM using daily or weekly betas could mis-estimate the true cost of equity by not properly considering the impact of known risk factors. Besides the importance of this for users of the CAPM in general, this result has particularly important policy implications for all utility regulators and competition authorities.

\section{References:}

Acker, D., \& Duck, N. W. (2007). Reference-day risk and the use of monthly returns data. Journal of Accounting, Auditing \& Finance, 22(4), 527-557.

Al-Horani, A., P. F. Pope and A. W. Stark (2003). Research and Development Activity and Expected Returns in the United Kingdom, European Finance Review Vol. 7, 27-46.

Amihud, Y. (2002). Illiquidity and stock returns: cross-section and time-series effects. Journal of financial markets, 5(1), 31-56.

Banz, R. W. (1981). The relationship between return and market value of common stocks. Journal of financial economics, 9(1), 3-18.

Blume, M. (1971). On the assessment of risk, Journal of Finance, 26, 1-10.

Blume, M. (1975). Betas and Regression tendencies. Journal of Finance, 30, 785-795

Buckland, R., Williams, J. \& Beecher, J. (2015). A cross-country comparison of evidence from the CAPM, Journal of Regulatory Economics, 47(2), 117-145

Bradshaw, M. T., Hutton, A. P., Marcus, A. J., \& Tehranian, H. (2009). Opaque Financial Reports, R-square, and Crash Risk," Journal of Financial Economics, 94, 67-86.

Brounen, D., de Jong, A., \& Koedijk, K. (2004). Corporate finance in Europe: confronting theory with practice. Financial Management, 33(4), 71-102.Brown, P., \& Walter, T. (2013). The CAPM: theoretical validity, empirical intractability and practical applications. Abacus, 49, Supplement , 44-50.

Cai, C. X., Clacher, I. \& Keasey, K. (2013). Consequences of the capital asset pricing model (CAPM) - a critical and broad perspective, Abacus, Supplement, 49, 51-61.

Campbell, J. Y., Polk, C., \& Vuolteenaho, T. (2010). Growth or glamour? Fundamentals and systematic risk in stock returns. Review of Financial Studies, 23(1), 305-344.

Cohen, K., Hawawini, G., Mayer, S., Schwartz, R., \& Whitcomb, D. (1980). Implications of microstructure theory for empirical research on stock price behavior. Journal of Finance, 35, 249-257.

Pinder, S., Coleman, L., \& Maheswaran, K. (2008). Managerial perspectives on corporate finance decisions. Dechow, P. M., Hutton, A. P., Kim, J. H., \& Sloan, R. G. (2012). 
Detecting earnings management: A new approach. Journal of Accounting Research, 50(2), 275-334.

Dempsey, M. (2013a). The Capital Asset Pricing Model (CAPM): The History of a Failed Revolutionary Idea in Finance?, Abacus, 49, Supplement, pp. 7-23.

Dempsey, M. (2013b). 'The CAPM: A Case of Elegance is for Tailors?', Abacus, 49, Supplement, pp. 82-87.

Dimson, E. (1979). Risk measurement when shares are subject to infrequent trading. Journal of Financial Economics, 7(2), 197-226.

Durack, N., Durand, R. B. \& Maller R. A. (2004). A best choice among asset pricing models? The conditional CAPM in Australia, Accounting and Finance 44, 139-162.

Fama, E. F., \& French, K. R. (1993). Common risk factors in the returns on stocks and bonds. Journal of financial economics, 33(1), 3-56.

Fama, E. F., \& French, K. R. (1996). Multifactor explanations of asset pricing anomalies. The journal of finance, 51(1), 55-84.

Fama, E. F., \& French, K. R. (2012). Size, Value, and Momentum in International Stock Returns, Journal of Financial Economics, 105, 457-472.

Fletcher, J. (2010). Arbitrage and the Evaluation of Linear Factor Models in UK Stock Returns, The Financial Review, Vol. 45, No.2, pp. 449-468.

Fletcher, J. \& J. Kihanda (2005). An examination of alternative CAPM-based models in UK stock returns, Journal of Banking \& Finance, 29, No. 12, pp. 2995-3014

Florackis, C., Gregoriou, A. \& Kostakis A. (2011). Trading Frequency and Asset Pricing on the London Stock Exchange: Evidence from a New Price Impact Ratio. Journal of Banking and Finance, Vol. 35, 3335-3350.

Gibbons, M. R., Ross, S. A., \& Shanken, J. (1989). A test of the efficiency of a given portfolio. Econometrica: Journal of the Econometric Society, 1121-1152.

Gilbert, T., Hrdlicka, C., Kalodimos, J., \& Siegel, S. (2014). Daily Data is Bad for Beta: Opacity and Frequency-Dependent Betas. Review of Asset Pricing Studies, 4(1), 78-117.

Gow, I.D., Ormazabal, G. \& Taylor, D.J. (2010). Correcting for Cross-Sectional and TimeSeries Dependence in Accounting Research. The Accounting Review, 85(2), 483-512.

Graham, J. R., \& Harvey, C. R. (2001). The theory and practice of corporate finance: Evidence from the field. Journal of financial economics, 60(2), 187-243.

Gregory, A., Tharyan, R., \& Christidis, A. (2013). Constructing and testing alternative versions of the Fama-French and Carhart models in the UK. Journal of Business Finance \& Accounting, 40(1-2), 172-214.

Handa, P., Kothari, S.P., \& Wasley, C. (1989). The relation between the return interval and betas: Implications for the size effect. Journal of Financial Economics, 23, 79-100.

Hambrick, D. C., \& Abrahamson, E. (1995). Assessing managerial discretion across industries: A multimethod approach. Academy of Management Journal, 38(5), 1427-1441. 
Hawawini, G. (1983). Why beta shifts as the return interval changes. Financial analysts journal, 73-77.

Jones, J. J. (1991). Earnings management during import relief investigations. Journal of accounting research, 193-228.

Levhari, D., \& Levy, H. (1977). The capital asset pricing model and the investment horizon, Review of Economics and Statistics, 59, 92-104.

Lewellen, J., S. Nagel and J. Shanken (2010). A Skeptical Appraisal of Asset-Pricing Tests, Journal of Financial Economics, Vol. 96, pp. 175-194.

McLaney, E., Pointon, J., Thomas, M., \& Tucker, J. (2004). Practitioners' perspectives on the UK cost of capital. The European Journal of Finance, 10(2), 123-138.

Manconi, A and Massa, M. Modigliani and Miller Meet Chandler: Organizational Complexity, Capital Structure, and Firm Value (September 1, 2009). Available at SSRN: http://ssrn.com/abstract=1359762

Miffre, J., Brooks, C. and Li, X., 2013. Idiosyncratic volatility and the pricing of poorlydiversified portfolios. International Review of Financial Analysis, 30, 78-85.

Moosa, I. A. (2013). The Capital Asset Pricing Model (CAPM): The History of a Failed Revolutionary Idea in Finance? Comments and Extensions, Abacus, 49, Supplement, 62-68.

Mouselli, S., Jaafar, A., \& Goddard, J. (2013). Accruals quality, stock returns and asset pricing: Evidence from the UK. International Review of Financial Analysis, 30, 203-213.

Partington, G. (2013). Death Where is Thy Sting? A Response to Dempsey's Despatching of the CAPM, Abacus, 49, Supplement, 1-6.

Petersen, M. A. (2009). Estimating standard errors in finance panel data sets: Comparing approaches. Review of financial studies, 22(1), 435-480.

Pope, P F and Stark, A W (1999) Are equities real(ly) options? Understanding the size, bookto-market and earnings-to-price factors. Working Paper. The Department of Accounting and Finance, Lancaster University.

Reinganum, M. R. (1982). A direct test of Roll's conjecture on the firm size effect. The Journal of Finance, 37(1), 27-35.

Scholes, M., \& J. Williams (1977). Estimating Betas from Nonsynchronous Data, Journal of Financial Economics, 5, 309-327.

Schrimpf, A., Schroder, M. \& Stehle, R. (2007). Cross-sectional tests of conditional asset pricing models: evidence from the German stock market', European Financial Management, 13(5), 880-907.

Sloan, R. G. (1996). Do Stock Prices Fully Reflect Information in Accruals and Cash Flows about Future Earnings? The Accounting Review, 71, 289-315

Smith, T. \& K. Walsh (2013). 'Why the CAPM is Half-right and Everything Else is Wrong', Abacus, 49, Supplement, 73-78. 
Sudarshanam, S., Kaltenbronn, U. \& Park, P. (2011). Cost of Equity for Regulated Companies: An international Comparison of Regulatory Practices, available at :

http://webarchive.nationalarchives.gov.uk/20140402141250/http:/www.competitioncommission.org.uk/assets/competitioncommission/docs/pdf/non-

inquiry/our_role/analysis/cost_of_equity_comparison_of_international_regulatory_practice.p df (last accessed 4th April 2016).

Zhang, Lu, (2005), The value premium, Journal of Finance 60, 67-103. 
Table 1: Summary Beta statistics

\begin{tabular}{|c|c|c|c|c|c|c|}
\hline \multirow{2}{*}{$\begin{array}{l}\text { Panel A } \\
\text { Return Frequency }\end{array}$} & \multicolumn{6}{|c|}{ UK Betas Before Dropping Extremes } \\
\hline & Obs & $\boldsymbol{\beta}_{\mathrm{EW}}$ & SD & Min & Max & $\beta_{\text {VW }}$ \\
\hline \multicolumn{7}{|c|}{ Conventional Estimation Period } \\
\hline Monthly & 4417 & $1.038 * * *$ & 0.490 & -0.457 & 4.105 & $0.894 * * *$ \\
\hline Weekly & 4417 & $0.853 * * *$ & 0.456 & -0.675 & 4.274 & $0.943 * * *$ \\
\hline Daily & 4417 & $0.729 * * *$ & 0.442 & -0.176 & 3.992 & $0.948 * * *$ \\
\hline Monthly-Weekly & 4417 & $0.185 * * *$ & 0.423 & -1.975 & 2.247 & $-0.049 * * *$ \\
\hline Monthly-Daily & 4417 & $0.309 * * *$ & 0.506 & -1.985 & 3.068 & $-0.054 * * *$ \\
\hline \multicolumn{7}{|c|}{ Common Estimation Period } \\
\hline Monthly & 4157 & $1.035 * * *$ & 0.500 & -0.457 & 4.105 & $0.888 * * *$ \\
\hline Weekly & 4157 & $0.841 * * *$ & 0.393 & -0.162 & 2.681 & $0.931 * * *$ \\
\hline Daily & 4157 & $0.702 * * *$ & 0.372 & 0.019 & 2.416 & $0.946 * * *$ \\
\hline Monthly-Weekly & 4157 & $0.194 * * *$ & 0.349 & -1.475 & 2.426 & $-0.043 * * *$ \\
\hline Monthly-Daily & 4157 & $0.333 * * *$ & 0.436 & -1.239 & 2.867 & $-0.058 * * *$ \\
\hline Panel B & \multicolumn{6}{|c|}{ UK Betas After Dropping Extremes } \\
\hline Return Frequency & Obs & $\boldsymbol{\beta}_{\mathrm{EW}}$ & SD & Min & Max & $\beta_{\text {VW }}$ \\
\hline \multicolumn{7}{|c|}{ Conventional Estimation Period } \\
\hline Monthly & 3975 & $1.011 * * *$ & 0.435 & -0.457 & 3.464 & $0.912 * * *$ \\
\hline Weekly & 3975 & $0.828 * * *$ & 0.417 & -0.329 & 2.831 & $0.880 * * *$ \\
\hline Monthly-Weekly & 3975 & $0.183 * * *$ & 0.309 & -0.464 & 0.884 & $0.032 * * *$ \\
\hline Monthly & 3975 & $1.010 * * *$ & 0.428 & -0.275 & 3.464 & $0.923 * * *$ \\
\hline Daily & 3975 & $0.707 * * *$ & 0.409 & -0.176 & 2.657 & $0.883 * * *$ \\
\hline Monthly-Daily & 3975 & $0.304 * * *$ & 0.392 & -0.487 & 1.128 & $0.040 * * *$ \\
\hline \multicolumn{7}{|c|}{ Common Estimation Period } \\
\hline Monthly & 3741 & $1.008 * * *$ & 0.425 & -0.182 & 2.823 & $0.915 * * *$ \\
\hline Weekly & 3741 & $0.823 * * *$ & 0.376 & -0.162 & 2.551 & $0.875^{* * *}$ \\
\hline Monthly-Weekly & 3741 & $0.186 * * *$ & 0.254 & -0.319 & 0.778 & $0.040 * * *$ \\
\hline Monthly & 3741 & $1.010 * * *$ & 0.414 & -0.162 & 2.776 & $0.941 * * *$ \\
\hline Daily & 3741 & $0.688 * * *$ & 0.365 & 0.019 & 2.416 & $0.887 * * *$ \\
\hline Monthly-Daily & 3741 & $0.322 * * *$ & 0.332 & -0.313 & 1.064 & $0.054 * * *$ \\
\hline
\end{tabular}

This table shows the summary statistics of the betas estimated by using monthly, weekly and daily returns. Panel A is based on observations where the extreme percentiles of Monthly $\beta$ Daily $\beta$ or Monthly $\beta$-Weekly $\beta$ have not been dropped. Panel B is based on observations where the extreme percentiles of Monthly $\beta$ - Daily $\beta$ or Monthly $\beta$-Weekly $\beta$ have been dropped. In each Panel, the first six rows are based on different estimation periods, and the second six rows are based on a common estimation period of five years. Obs. is the number of firm-year observations. Monthly-Weekly is the difference in the Monthly and Weekly betas, and Monthly-Daily is the difference in Monthly and Daily betas. $\beta_{\mathrm{EW}}$ is the equal weighted beta and $\beta_{\mathrm{Vw}}$ is the value weighted beta. $* * *, * *$ and $*$ denotes the significance at $1 \%, 5 \%$ and $10 \%$ respectively. 
Table 2: Descriptive statistics, Monthly vs Daily Sample

\section{Conventional Estimation Period}

Panel A: Means, standard deviations and medians

\begin{tabular}{|l|l|l|l|l|}
\hline Variable & \multicolumn{1}{|c|}{ Obs } & Mean & \multicolumn{1}{c|}{ SD } & \multicolumn{1}{c|}{ Median } \\
\hline$\Delta$ Beta & 3975 & $0.304^{* * *}$ & 0.392 & 0.298 \\
\hline Size & 3975 & $0.003^{* * *}$ & 0.006 & 0.001 \\
\hline AAA & 3975 & $0.040^{* * *}$ & 0.047 & 0.026 \\
\hline R_to_TR & 3975 & $1.413 * * *$ & 2.583 & 0.713 \\
\hline TD/ME & 3975 & $0.334 * * *$ & 0.482 & 0.228 \\
\hline BE/ME & 3975 & $0.480 * * *$ & 0.413 & 0.391 \\
\hline
\end{tabular}

Panel B: Correlations:

\begin{tabular}{|c|c|c|c|c|c|c|}
\hline Variable & $\Delta$ Beta & Size & $\mathbf{A A A}$ & R_to_TR & TD/ME & BE/ME \\
\hline$\Delta$ Beta & 1.00 & & & & & \\
\hline Size & $-0.29 * * *$ & 1.00 & & & & \\
\hline AAA & $0.06 * * *$ & $-0.08 * * *$ & 1.00 & & & \\
\hline R_to_TR & $0.20 * * *$ & $-0.11 * * *$ & $0.06 * * *$ & 1.00 & & \\
\hline TD/ME & 0.02 & -0.03 & $-0.07 * * *$ & $0.07 * * *$ & 1.00 & \\
\hline $\mathrm{BE} / \mathrm{ME}$ & $0.07 * * *$ & -0.02 & $-0.11 * * *$ & 0.02 & $0.41 * * *$ & 1.00 \\
\hline
\end{tabular}

\section{Common Estimation Period}

Panel C: Means, standard deviations and medians

\begin{tabular}{|l|l|l|l|l|}
\hline Variable & \multicolumn{1}{|c|}{ Obs } & \multicolumn{1}{c|}{ Mean } & \multicolumn{1}{c|}{ SD } & \multicolumn{1}{c|}{ Median } \\
\hline$\Delta$ Beta & 3741 & $0.322^{* * *}$ & 0.332 & 0.319 \\
\hline Size & 3741 & $0.002^{* * *}$ & 0.006 & 0.001 \\
\hline AAA & 3741 & $0.040^{* * *}$ & 0.046 & 0.026 \\
\hline R_to_TR & 3741 & $1.400^{* * *}$ & 2.459 & 0.716 \\
\hline TD/ME & 3741 & $0.330^{* * *}$ & 0.487 & 0.221 \\
\hline BE/ME & 3741 & $0.484 * * *$ & 0.442 & 0.387 \\
\hline
\end{tabular}

Panel D: Correlations:

\begin{tabular}{|l|l|l|l|l|l|l|}
\hline Variable & \multicolumn{1}{|c|}{$\mathbf{\Delta B e t a}$} & \multicolumn{1}{|c|}{ Size } & AAA & R_to_TR & TD/ME & BE/ME \\
\hline$\Delta$ Beta & 1.00 & & & & & \\
\hline Size & $-0.33 * * *$ & 1.00 & & & & \\
\hline AAA & $0.10 * * *$ & $-0.09 * * *$ & 1.00 & & & \\
\hline R_to_TR & $0.19 * * *$ & $-0.11 * * *$ & $0.06 * * *$ & 1.00 & & \\
\hline TD/ME & 0.00 & -0.02 & $-0.07 * * *$ & $0.08 * * *$ & 1.00 & \\
\hline BE/ME & $0.05 * * *$ & $-0.04 * *$ & $-0.08 * * *$ & $0.03 *$ & $0.45 * * *$ & 1.00 \\
\hline
\end{tabular}

This table shows the summary statistics for the measures of opacity, Size and illiquidity, plus control variables. Where $\triangle B$ Beta is the difference between monthly and daily betas, $A A A$ is the Winsorised absolute value of abnormal accruals from the estimation of Modified Jones (1991) model, Size is the firm's market capitalisation as a percentage of total market capitalisation, R_to_TR, is the Winsorised illiquidity ratio from Florackis et al. (2011), $\mathrm{TD} / \mathrm{ME}$ is the gearing ratio calculated as total debt/market value of equity, and BE/ME is the book value of equity to the market value of equity. For a detailed explanation of the measures and precise descriptions of the year end dates used, see text. Panels A \& B are based on different (conventional) estimation periods, Panels $\mathrm{C} \& \mathrm{D}$ are based on common estimation periods. $* * * * *$ and $*$ denotes the significance at $1 \%, 5 \%$ and $10 \%$ respectively. 
Table 3: Descriptive statistics, Monthly vs Weekly Sample

\section{Conventional Estimation Period}

Panel A: Means, standard deviations and medians

\begin{tabular}{|l|l|l|l|l|}
\hline Variable & \multicolumn{1}{|c|}{ Obs } & \multicolumn{1}{c|}{ Mean } & \multicolumn{1}{c|}{ SD } & \multicolumn{1}{c|}{ Median } \\
\hline$\Delta$ Beta & 3975 & $0.183^{* * *}$ & 0.309 & 0.171 \\
\hline Size & 3975 & $0.003 * * *$ & 0.006 & 0.001 \\
\hline AAA & 3975 & $0.040^{* * *}$ & 0.047 & 0.026 \\
\hline R_to_TR & 3975 & $1.400 * * *$ & 2.584 & 0.700 \\
\hline TD/ME & 3975 & $0.336 * * *$ & 0.489 & 0.228 \\
\hline BE/ME & 3975 & $0.488^{* * *}$ & 0.430 & 0.396 \\
\hline
\end{tabular}

Panel B: Correlations:

\begin{tabular}{|l|l|l|l|l|l|l|}
\hline Variable & \multicolumn{1}{|c|}{$\mathbf{\Delta B e t a}$} & \multicolumn{1}{|c|}{ Size } & AAA & R_to_TR & TD/ME & BE/ME \\
\hline$\Delta$ Beta & 1.00 & & & & & \\
\hline Size & $-0.22^{* * *}$ & 1.00 & & & & \\
\hline AAA & $0.05^{* * *}$ & $-0.09^{* * *}$ & 1.00 & & & \\
\hline R_to_TR & $0.15^{* * *}$ & $-0.11^{* * *}$ & $0.07 * * *$ & 1.00 & & \\
\hline TD/ME & 0.01 & $-0.03^{*}$ & $-0.08^{* * *}$ & $0.06^{* * *}$ & 1.00 & \\
\hline BE/ME & $0.05^{* * *}$ & -0.02 & $-0.10^{* * *}$ & 0.01 & $0.45^{* * *}$ & 1.00 \\
\hline Con &
\end{tabular}

\section{Common Estimation Period}

Panel C: Means, standard deviations and medians

\begin{tabular}{|l|l|l|l|l|}
\hline Variable & \multicolumn{1}{|c|}{ Obs } & \multicolumn{1}{c|}{ Mean } & \multicolumn{1}{c|}{ SD } & \multicolumn{1}{c|}{ Median } \\
\hline$\Delta$ Beta & 3741 & $0.186^{* * *}$ & 0.254 & 0.171 \\
\hline Size & 3741 & $0.002^{* * *}$ & 0.006 & 0.001 \\
\hline AAA & 3741 & $0.040 * * *$ & 0.046 & 0.026 \\
\hline R_to_TR & 3741 & $1.404 * * *$ & 2.477 & 0.720 \\
\hline TD/ME & 3741 & $0.327 * * *$ & 0.474 & 0.221 \\
\hline BE/ME & 3741 & $0.489 * * *$ & 0.435 & 0.391 \\
\hline
\end{tabular}

Panel D: Correlations:

\begin{tabular}{|l|l|l|l|l|l|l|}
\hline Variable & \multicolumn{1}{|c|}{$\mathbf{\Delta B e t a}$} & \multicolumn{1}{|c|}{ Size } & AAA & R_to_TR & TD/ME & BE/ME \\
\hline$\Delta$ Beta & 1.00 & & & & & \\
\hline Size & $-0.24^{* * *}$ & 1.00 & & & & \\
\hline AAA & $0.07 * * *$ & $-0.09 * * *$ & 1.00 & & & \\
\hline R_to_TR & $0.16^{* * *}$ & $-0.11^{* * *}$ & $0.06^{* * *}$ & 1.00 & & \\
\hline TD/ME & 0.01 & -0.02 & $-0.07 * * *$ & $0.08 * * *$ & 1.00 & \\
\hline BE/ME & $0.05^{* * *}$ & $-0.04 * *$ & $-0.08^{* * *}$ & 0.03 & $0.46^{* * *}$ & 1.00 \\
\hline
\end{tabular}

This table shows the summary statistics for the measures of opacity, size and illiquidity, plus control variables. Where $\triangle B$ eta is the difference between monthly and weekly betas, $A A A$ is the Winsorised absolute value of abnormal accruals from the estimation of Modified Jones (1991) model, Size is the firm's market capitalisation as a percentage of total market capitalisation, R_to_TR, is the Winsorised illiquidity ratio from Florackis et al. (2011), $\mathrm{TD} / \mathrm{ME}$ is the gearing ratio calculated as total debt/market value of equity, and BE/ME is the book value of equity to the market value of equity. For a detailed explanation of the measures and precise descriptions of the year end dates used, see text. Panels A \& B are based on different (conventional) estimation periods, Panels $\mathrm{C} \& \mathrm{D}$ are based on common estimation periods. $* * *, * *$ and $*$ denotes the significance at $1 \%, 5 \%$ and $10 \%$ respectively. 
Table 4: Explaining the difference in Monthly vs Daily betas

\begin{tabular}{|c|c|c|c|c|}
\hline Estimation period & \multicolumn{2}{|c|}{ Conventional Estimation Period } & \multicolumn{2}{|c|}{ Common Estimation Period } \\
\hline Model & Full1 & Full2 & Full3 & Full4 \\
\hline AAA & $\begin{array}{l}0.293 * \\
(0.157)\end{array}$ & $\begin{array}{l}0.270 \\
(0.172)\end{array}$ & $\begin{array}{l}0.439 * * * \\
(0.138)\end{array}$ & $\begin{array}{l}0.377 * * * \\
(0.140)\end{array}$ \\
\hline Size & $\begin{array}{l}-17.000 * * * \\
(5.304)\end{array}$ & $\begin{array}{l}-15.365^{* * *} \\
(5.077)\end{array}$ & $\begin{array}{l}-18.427 * * * \\
(6.389)\end{array}$ & $\begin{array}{l}-16.787 * * * \\
(5.387)\end{array}$ \\
\hline R_to_TR & $\begin{array}{l}0.025 * * * \\
(0.005)\end{array}$ & $\begin{array}{l}0.022 * * * \\
(0.004)\end{array}$ & $\begin{array}{l}0.021 * * * \\
(0.004)\end{array}$ & $\begin{array}{l}0.018 * * * \\
(0.004)\end{array}$ \\
\hline $\mathrm{TD} / \mathrm{ME}$ & $\begin{array}{l}-0.023 \\
(0.021)\end{array}$ & $\begin{array}{l}-0.014 \\
(0.022)\end{array}$ & $\begin{array}{l}-0.030 \\
(0.019)\end{array}$ & $\begin{array}{l}-0.014 \\
(0.018)\end{array}$ \\
\hline $\mathrm{BE} / \mathrm{ME}$ & $\begin{array}{l}0.077 * * \\
(0.031)\end{array}$ & $\begin{array}{l}0.098 * * * \\
(0.030)\end{array}$ & $\begin{array}{l}0.045 \\
(0.032)\end{array}$ & $\begin{array}{l}0.059 * \\
(0.032)\end{array}$ \\
\hline intercept & $\begin{array}{l}0.270 * * * \\
(0.039)\end{array}$ & & $\begin{array}{l}0.303 * * * \\
(0.031)\end{array}$ & \\
\hline $\mathrm{N}$ & 3975 & 3975 & 3741 & 3741 \\
\hline $\mathrm{R}^{2}$ & 0.115 & 0.481 & 0.140 & 0.594 \\
\hline Industry Dummies? & $\mathrm{N}$ & $\mathrm{Y}$ & $\mathrm{N}$ & $\mathrm{Y}$ \\
\hline
\end{tabular}

The full version of the model is:

$$
\Delta \beta_{i t}=a+b . A A A_{i t-1}+c . S i z e_{i t-1}+d_{.} R_{-} t o_{-} T R_{i t-1}+e . B E / M E_{i t-1}+e . T D / M E_{i t-1}+\sum i . I N D_{i t}+\epsilon_{i t}
$$

Full 1 includes all control variables but no industry dummies, whilst Full 2 includes all control variables plus industry dummies (no-intercept), both models using conventional estimation periods (5-years for monthly beta, 1-year for daily beta). Full 3 includes all control variables but no industry dummies, whilst Full 4 includes all control variables plus industry dummies (no-intercept), both models using common estimation periods (5-years for monthly beta, 5 -years for daily beta). $\Delta \beta$ is $\mathrm{M} \beta$ - $\mathrm{D} \beta$, the difference between monthly and daily betas. Standard errors are clustered by firm and year. $A A A$ is the Winsorised absolute value of abnormal accruals from the estimation of Modified Jones (1991) model, Size is the firm's market capitalisation as a percentage of total market capitalisation, $R \_t o \_T R$, is the Winsorised illiquidity ratio from Florackis et al. (2011), TD/ME is the gearing ratio calculated as total debt/market value of equity, and $\mathrm{BE} / \mathrm{ME}$ is the book value of equity to the market value of equity. For a detailed explanation of the measures and precise descriptions of the year end dates used, see text. Industry dummies are included where indicated. For a detailed explanation of the measures and industry classification see text. $\mathrm{R}^{2}$ is the adjusted R-Squared. For each independent variable, we show the coefficient in the first row and standard errors in the second row. $* * * * *$ and $*$ denotes the significance at $1 \%, 5 \%$ and $10 \%$ respectively. 
Table 5: Explaining the difference in Monthly vs Weekly betas

\begin{tabular}{|c|c|c|c|c|}
\hline Estimation period & \multicolumn{2}{|c|}{ Conventional Estimation Period } & \multicolumn{2}{|c|}{ Common Estimation Period } \\
\hline Model & Full1 & Full2 & Full3 & Full4 \\
\hline AAA & $\begin{array}{l}0.147 \\
(0.109)\end{array}$ & $\begin{array}{l}0.148 \\
(0.121)\end{array}$ & $\begin{array}{l}0.271 * * \\
(0.108)\end{array}$ & $\begin{array}{l}0.254 * * \\
(0.107)\end{array}$ \\
\hline Size & $\begin{array}{l}-10.378 * * * \\
(3.064)\end{array}$ & $\begin{array}{l}-9.317 * * * \\
(3.118)\end{array}$ & $\begin{array}{l}-9.290^{* * *} \\
(3.194)\end{array}$ & $\begin{array}{l}-8.507 * * * \\
(2.801)\end{array}$ \\
\hline R_to_TR & $\begin{array}{l}0.016 \text { *** } \\
(0.003)\end{array}$ & $\begin{array}{l}0.013 * * * \\
(0.003)\end{array}$ & $\begin{array}{l}0.014 * * * \\
(0.003)\end{array}$ & $\begin{array}{l}0.012 * * * \\
(0.003)\end{array}$ \\
\hline TD/ME & $\begin{array}{l}-0.020 \\
(0.017)\end{array}$ & $\begin{array}{l}-0.018 \\
(0.018)\end{array}$ & $\begin{array}{l}-0.015 \\
(0.015)\end{array}$ & $\begin{array}{l}-0.010 \\
(0.015)\end{array}$ \\
\hline $\mathrm{BE} / \mathrm{ME}$ & $\begin{array}{l}0.043^{* *} \\
(0.022)\end{array}$ & $\begin{array}{l}0.056 * * * \\
(0.022)\end{array}$ & $\begin{array}{l}0.033 \\
(0.021)\end{array}$ & $\begin{array}{l}0.045 * * \\
(0.021)\end{array}$ \\
\hline intercept & $\begin{array}{l}0.167 * * * \\
(0.026)\end{array}$ & & $\begin{array}{l}0.165^{* * *} \\
(0.020)\end{array}$ & \\
\hline $\mathrm{N}$ & 3975 & 3975 & 3741 & 3741 \\
\hline $\mathrm{R}^{2}$ & 0.068 & 0.336 & 0.080 & 0.435 \\
\hline Industry Dummies? & $\mathrm{N}$ & $\mathrm{Y}$ & $\mathrm{N}$ & $\mathrm{Y}$ \\
\hline
\end{tabular}

The full version of the model is:

$$
\Delta \beta_{i t}=a+b . A A A_{i t-1}+c . \text { Size }_{i t-1}+d_{.} R_{-} t o_{-} T R_{i t-1}+e . B E / M E_{i t-1}+e . T D / M E_{i t-1}+\sum i . I N D_{i t}+\epsilon_{i t}
$$

Full 1 includes all control variables but no industry dummies, whilst Full 2 includes all control variables plus industry dummies (no-intercept), both models using conventional estimation periods (5-years for monthly beta, 2-years for weekly beta). Full 3 includes all control variables but no industry dummies, whilst Full 4 includes all control variables plus industry dummies (no-intercept), both models using common estimation periods (5-years for monthly beta, 5-years for weekly beta). $\Delta \beta$ is $\mathrm{M} \beta-\mathrm{W} \beta$, the difference between monthly and weekly betas. Standard errors are clustered by firm and year. $A A A$ is the Winsorised absolute value of abnormal accruals from the estimation of Modified Jones (1991) model, Size is the firm's market capitalisation as a percentage of total market capitalisation, $R_{-} t t_{-} T R$, is the Winsorised illiquidity ratio from Florackis et al. (2011), TD/ME is the gearing ratio calculated as total debt/market value of equity, and BE/ME is the book value of equity to the market value of equity. For a detailed explanation of the measures and precise descriptions of the year end dates used, see text. Industry dummies are included where indicated. For a detailed explanation of the measures and industry classification see text. $\mathrm{R}^{2}$ is the adjusted R-Squared. For each independent variable, we show the coefficient in the first row and standard errors in the second row. $* * * * *$ and $*$ denotes the significance at $1 \%, 5 \%$ and $10 \%$ respectively. 
Table 6: Industry Dummies for models Full 2 and Full 4.

\begin{tabular}{|c|c|c|c|c|}
\hline $\begin{array}{c}\text { Estimation } \\
\text { Period } \\
\end{array}$ & $\begin{array}{c}\text { Conventional } \\
\text { Estimation } \\
\text { Period } \\
\end{array}$ & $\begin{array}{c}\text { Common } \\
\text { Estimation } \\
\text { Period } \\
\end{array}$ & $\begin{array}{c}\text { Conventional } \\
\text { Estimation } \\
\text { Period } \\
\end{array}$ & $\begin{array}{c}\text { Common } \\
\text { Estimation } \\
\text { Period } \\
\end{array}$ \\
\hline \multirow{2}{*}{ Industry } & \multicolumn{2}{|c|}{ Monthly - Daily beta } & \multicolumn{2}{|c|}{ Monthly - Weekly beta } \\
\hline & Full 2 & Full 4 & Full 2 & Full 4 \\
\hline BRESR & $\begin{array}{l}0.2259 * * * \\
(0.066)\end{array}$ & $\begin{array}{l}0.2750 * * * \\
(0.052)\end{array}$ & $\begin{array}{l}0.1235^{* * *} \\
(0.053)\end{array}$ & $\begin{array}{l}0.1416 * * * \\
(0.037)\end{array}$ \\
\hline CHMCL & $\begin{array}{l}0.3392 * * * \\
(0.055)\end{array}$ & $\begin{array}{l}0.3390 * * * \\
(0.056)\end{array}$ & $\begin{array}{l}0.1970 * * * \\
(0.038)\end{array}$ & $\begin{array}{l}0.1649 * * * \\
(0.038)\end{array}$ \\
\hline CNSTM & $\begin{array}{l}0.3276 * * * \\
(0.063)\end{array}$ & $\begin{array}{l}0.3197 * * * \\
(0.041)\end{array}$ & $\begin{array}{l}0.1710^{* * * *} \\
(0.043)\end{array}$ & $\begin{array}{l}0.1487 \text { *** } \\
(0.031)\end{array}$ \\
\hline FDBEV & $\begin{array}{l}0.0927 * \\
(0.055)\end{array}$ & $\begin{array}{l}0.1291 * * * \\
(0.047)\end{array}$ & $\begin{array}{l}0.0602 * \\
(0.033)\end{array}$ & $\begin{array}{l}0.0564 * * \\
(0.029)\end{array}$ \\
\hline HLTHC & $\begin{array}{l}0.2180 * * * \\
(0.067)\end{array}$ & $\begin{array}{l}0.2465 * * * \\
(0.068)\end{array}$ & $\begin{array}{l}0.1137 * * \\
(0.045)\end{array}$ & $\begin{array}{l}0.1042 * * \\
(0.041)\end{array}$ \\
\hline INDGS & $\begin{array}{l}0.3424 * * * \\
(0.041)\end{array}$ & $\begin{array}{l}0.3840 * * * \\
(0.032)\end{array}$ & $\begin{array}{l}0.2127 * * * \\
(0.028)\end{array}$ & $\begin{array}{l}0.2167 * * * \\
(0.023)\end{array}$ \\
\hline MEDIA & $\begin{array}{l}0.3477 * * * \\
(0.053)\end{array}$ & $\begin{array}{l}0.3538 * * * \\
(0.060)\end{array}$ & $\begin{array}{l}0.2656 * * * \\
(0.040)\end{array}$ & $\begin{array}{l}0.2444 * * * \\
(0.051)\end{array}$ \\
\hline OILGS & $\begin{array}{l}0.2097 * * * \\
(0.075)\end{array}$ & $\begin{array}{l}0.3329 * * * \\
(0.066)\end{array}$ & $\begin{array}{l}0.1122 * \\
(0.059)\end{array}$ & $\begin{array}{l}0.1704 * * * \\
(0.047)\end{array}$ \\
\hline PERHH & $\begin{array}{l}0.2491 * * * \\
(0.067)\end{array}$ & $\begin{array}{l}0.3134 * * * \\
(0.053)\end{array}$ & $\begin{array}{l}0.1512 * * * \\
(0.044)\end{array}$ & $\begin{array}{l}0.1582 * * * \\
(0.034)\end{array}$ \\
\hline RTAIL & $\begin{array}{l}0.1482 * * * \\
(0.043)\end{array}$ & $\begin{array}{l}0.1840 * * * \\
(0.039)\end{array}$ & $\begin{array}{l}0.1054 * * * \\
(0.031)\end{array}$ & $\begin{array}{l}0.0959 * * * \\
(0.028)\end{array}$ \\
\hline TECNO & $\begin{array}{l}0.2687 * * * \\
(0.050)\end{array}$ & $\begin{array}{l}0.3073 * * * \\
(0.045)\end{array}$ & $\begin{array}{l}0.1300 * * * \\
(0.027)\end{array}$ & $\begin{array}{l}0.1691 * * * \\
(0.024)\end{array}$ \\
\hline TELCM & $\begin{array}{l}0.6199 * * * \\
(0.143)\end{array}$ & $\begin{array}{l}0.3962 * * * \\
(0.116)\end{array}$ & $\begin{array}{l}0.4767 * * * \\
(0.148)\end{array}$ & $\begin{array}{l}\text { 0.4956*** } \\
(0.088)\end{array}$ \\
\hline TRLES & $\begin{array}{l}0.2149 * * * \\
(0.055)\end{array}$ & $\begin{array}{l}0.2549 * * * \\
(0.045)\end{array}$ & $\begin{array}{l}0.1694 * * * \\
(0.046)\end{array}$ & $\begin{array}{l}0.1598 \text { *** } \\
(0.036)\end{array}$ \\
\hline UTILS & $\begin{array}{l}0.0475 \\
(0.081)\end{array}$ & $\begin{array}{l}0.0528 \\
(0.061)\end{array}$ & $\begin{array}{l}0.0214 \\
(0.054)\end{array}$ & $\begin{array}{l}0.0186 \\
(0.043)\end{array}$ \\
\hline
\end{tabular}

This table shows the basic Datastream Level 3 industry classifications. Dummies are from models Full 2 and Full 4 in tables 4 and 5. Full 2 is based on conventional estimation periods, while Full 4 is based on common estimation periods. Column 1 and 2 are monthly verses daily, while Column 3 and 4 are monthly verses weekly. 
Table 7: Explaining the difference in Betas -Monthly vs Daily betas, restricted sample

\begin{tabular}{|c|c|c|c|c|c|c|c|c|}
\hline \multirow{4}{*}{ Model } & \\
\hline & \multicolumn{4}{|c|}{ Conventional Estimation Period } & \multicolumn{4}{|c|}{ Common Estimation Period } \\
\hline & Large & Large & Liquid & Liquid & Large & Large & Liquid & Liquid \\
\hline & Restrict 1 & Restrict 2 & Restrict 3 & Restrict 4 & Restrict 1 & Restrict 2 & Restrict 3 & Restrict 4 \\
\hline AAA & $\begin{array}{l}0.142 \\
(0.229)\end{array}$ & $\begin{array}{l}0.127 \\
(0.241)\end{array}$ & $\begin{array}{l}0.324 \\
(0.247)\end{array}$ & $\begin{array}{l}0.202 \\
(0.244)\end{array}$ & $\begin{array}{l}0.324 \\
(0.226)\end{array}$ & $\begin{array}{l}0.269 \\
(0.203)\end{array}$ & $\begin{array}{l}0.554 * * \\
(0.231)\end{array}$ & $\begin{array}{l}0.402 * * \\
(0.201)\end{array}$ \\
\hline Size & $\begin{array}{l}-11.688^{* * * *} \\
(3.915)\end{array}$ & $\begin{array}{l}-11.400 \text { *** } \\
(3.865)\end{array}$ & $\begin{array}{l}-15.326^{* * * *} \\
(4.478)\end{array}$ & $\begin{array}{l}-16.014 * * * \\
(5.070)\end{array}$ & $\begin{array}{l}-12.294 * * * \\
(4.575)\end{array}$ & $\begin{array}{l}-10.866 \text { *** } \\
(3.980)\end{array}$ & $\begin{array}{l}-17.873 * * * \\
(5.785)\end{array}$ & $\begin{array}{l}-16.427 * * * \\
(5.293)\end{array}$ \\
\hline R_to_TR & $\begin{array}{l}0.025 * * * \\
(0.006)\end{array}$ & $\begin{array}{l}0.021 * * * \\
(0.005)\end{array}$ & $\begin{array}{l}0.314 * * * \\
(0.075)\end{array}$ & $\begin{array}{l}0.300^{* * * *} \\
(0.073)\end{array}$ & $\begin{array}{l}0.020 * * * \\
(0.005)\end{array}$ & $\begin{array}{l}0.015 * * * \\
(0.004)\end{array}$ & $\begin{array}{l}0.158 * * \\
(0.069)\end{array}$ & $\begin{array}{l}0.127 * \\
(0.065)\end{array}$ \\
\hline TD/ME & $\begin{array}{l}0.006 \\
(0.024)\end{array}$ & $\begin{array}{l}0.006 \\
(0.022)\end{array}$ & $\begin{array}{l}0.037 \\
(0.035)\end{array}$ & $\begin{array}{l}0.050 \\
(0.038)\end{array}$ & $\begin{array}{l}0.002 \\
(0.022)\end{array}$ & $\begin{array}{l}0.007 \\
(0.020)\end{array}$ & $\begin{array}{l}0.020 \\
(0.033)\end{array}$ & $\begin{array}{l}0.037 \\
(0.033)\end{array}$ \\
\hline $\mathrm{BE} / \mathrm{ME}$ & $\begin{array}{l}0.058 \\
(0.041)\end{array}$ & $\begin{array}{l}0.084^{* *} \\
(0.040)\end{array}$ & $\begin{array}{l}0.053 \\
(0.034)\end{array}$ & $\begin{array}{l}0.056^{*} \\
(0.033)\end{array}$ & $\begin{array}{l}0.028 \\
(0.044)\end{array}$ & $\begin{array}{l}0.049 \\
(0.047)\end{array}$ & $\begin{array}{l}0.039 \\
(0.038)\end{array}$ & $\begin{array}{l}0.042 \\
(0.038)\end{array}$ \\
\hline intercept & $\begin{array}{l}0.173 * * * \\
(0.042)\end{array}$ & & $\begin{array}{l}0.061 \\
(0.048) \\
\end{array}$ & & $\begin{array}{l}0.192 * * * \\
(0.036)\end{array}$ & & $\begin{array}{l}0.146^{* * * *} \\
(0.048) \\
\end{array}$ & \\
\hline $\mathrm{N}$ & 1995 & 1995 & 1995 & 1995 & 1876 & 1876 & 1876 & 1876 \\
\hline $\mathrm{R}^{2}$ & 0.094 & 0.297 & 0.126 & 0.364 & 0.112 & 0.401 & 0.131 & 0.442 \\
\hline $\begin{array}{l}\text { Industry } \\
\text { Dummies? }\end{array}$ & $\mathrm{N}$ & $\mathrm{Y}$ & $\mathrm{N}$ & $\mathrm{Y}$ & $\mathrm{N}$ & $\mathrm{Y}$ & $\mathrm{N}$ & $\mathrm{Y}$ \\
\hline
\end{tabular}

The full version of the model is: $\Delta \beta_{i t}=a+b . A A A_{i t-1}+c . S i z e_{i t-1}+d . R_{-} t o_{-} T R_{i t-1}+e . B E / M E_{i t-1}+e . T D / M E_{i t-1}+\sum i . I N D_{i t}+\epsilon_{i t}$

The first group of models(restrict 1\&2) restricts the sample to cases where Size is above the median. Restrict 1 includes all control variables but no industry dummies, whilst Restrict 2 includes all control variables plus industry dummies (no-intercept). The second group of models (restrict $3 \& 4$ ) restricts the sample to cases where illiquidity measure is below the median (that is, the most liquid companies). Restrict 3 includes all control variables but no industry dummies, whilst Restrict 4 includes all control variables plus industry dummies (no-intercept). $\Delta \beta$ is $M \beta$-D $\beta$, the difference between monthly and daily betas. First four columns are based on coventional estimation periods; the second four then repeat these for a common estimation period. Standard errors are clustered by firm and year. $A A A$ is the Winsorised absolute value of abnormal accruals from the estimation of Modified Jones (1991) model, Size is the firm's market capitalisation as a percentage of total market capitalisation, $R \_t o \_T R$, is the Winsorised illiquidity ratio from Florackis et al. (2011), TD/ME is the gearing ratio calculated as total debt/market value of equity, and BE/ME is the book value of equity to the market value of equity. For a detailed explanation of the measures and precise descriptions of the year end dates used, see text. Industry dummies are included where indicated. $\mathrm{R}^{2}$ is the adjusted R-Squared. For each independent variable, we show the coefficient in the first row and standard errors in the second row. $* * * * *$ and $*$ denotes the significance at $1 \%, 5 \%$ and $10 \%$ respectively. 
Table 8: Explaining the difference in Betas -Monthly vs Weekly betas, restricted sample

\begin{tabular}{|c|c|c|c|c|c|c|c|c|}
\hline \multirow{2}{*}{ Model } & \multicolumn{4}{|c|}{ Conventional Estimation Period } & \multicolumn{4}{|c|}{ Common Estimation Period } \\
\hline & Restrict 1 & Restrict 2 & Restrict 3 & Restrict 4 & Restrict 1 & Restrict 2 & Restrict 3 & Restrict 4 \\
\hline AAA & $\begin{array}{l}0.136 \\
(0.153)\end{array}$ & $\begin{array}{l}0.136 \\
(0.149)\end{array}$ & $\begin{array}{l}0.135 \\
(0.172)\end{array}$ & $\begin{array}{l}0.097 \\
(0.178)\end{array}$ & $\begin{array}{l}0.328^{*} \\
(0.171)\end{array}$ & $\begin{array}{l}0.295^{*} \\
(0.157)\end{array}$ & $\begin{array}{l}0.336^{*} \\
(0.176)\end{array}$ & $\begin{array}{l}0.233 \\
(0.162)\end{array}$ \\
\hline Size & $\begin{array}{l}-6.949 * * * \\
(2.318)\end{array}$ & $\begin{array}{l}-6.656^{* * * *} \\
(2.486)\end{array}$ & $\begin{array}{l}-8.645^{* * * *} \\
(2.454)\end{array}$ & $\begin{array}{l}-9.173 * * * \\
(2.953)\end{array}$ & $\begin{array}{l}-5.605^{* * *} \\
(2.088)\end{array}$ & $\begin{array}{l}-5.070 * * \\
(2.004)\end{array}$ & $\begin{array}{l}-7.302 * * * \\
(2.663)\end{array}$ & $\begin{array}{l}-7.072 * * * \\
(2.734)\end{array}$ \\
\hline R_to_TR & $\begin{array}{l}0.015 * * * \\
(0.004)\end{array}$ & $\begin{array}{l}0.013 * * * \\
(0.004)\end{array}$ & $\begin{array}{l}0.138^{*} \\
(0.075)\end{array}$ & $\begin{array}{l}0.133^{*} \\
(0.076)\end{array}$ & $\begin{array}{l}0.013 * * * \\
(0.003)\end{array}$ & $\begin{array}{l}0.010 * * * \\
(0.003)\end{array}$ & $\begin{array}{l}0.114^{*} \\
(0.058)\end{array}$ & $\begin{array}{l}0.105^{*} \\
(0.055)\end{array}$ \\
\hline $\mathrm{TD} / \mathrm{ME}$ & $\begin{array}{l}0.009 \\
(0.035)\end{array}$ & $\begin{array}{l}0.023 \\
(0.035)\end{array}$ & $\begin{array}{l}0.005 \\
(0.031)\end{array}$ & $\begin{array}{l}0.012 \\
(0.034)\end{array}$ & $\begin{array}{l}0.005 \\
(0.029)\end{array}$ & $\begin{array}{l}0.014 \\
(0.028)\end{array}$ & $\begin{array}{l}0.017 \\
(0.027)\end{array}$ & $\begin{array}{l}0.024 \\
(0.027)\end{array}$ \\
\hline $\mathrm{BE} / \mathrm{ME}$ & $\begin{array}{l}0.052 * \\
(0.029)\end{array}$ & $\begin{array}{l}0.068^{* *} \\
(0.033)\end{array}$ & $\begin{array}{l}0.048 * * \\
(0.020)\end{array}$ & $\begin{array}{l}0.052 * * \\
(0.021)\end{array}$ & $\begin{array}{l}0.053^{*} \\
(0.030)\end{array}$ & $\begin{array}{l}0.060^{*} \\
(0.032)\end{array}$ & $\begin{array}{l}0.039 \\
(0.024)\end{array}$ & $\begin{array}{l}0.039 \\
(0.025)\end{array}$ \\
\hline intercept & $\begin{array}{l}0.091 * * * \\
(0.030)\end{array}$ & & $\begin{array}{l}0.060 \\
(0.041)\end{array}$ & & $\begin{array}{l}0.077 * * * \\
(0.024)\end{array}$ & & $\begin{array}{l}0.052 \\
(0.034)\end{array}$ & \\
\hline $\mathrm{N}$ & 1995 & 1995 & 1994 & 1994 & 1875 & 1875 & 1875 & 1875 \\
\hline $\mathrm{R}^{2}$ & 0.053 & 0.180 & 0.052 & 0.219 & 0.061 & 0.249 & 0.066 & 0.287 \\
\hline Industry Dummies? & $\mathrm{N}$ & $\mathrm{Y}$ & $\mathrm{N}$ & $\mathrm{Y}$ & $\mathrm{N}$ & Y & $\mathrm{N}$ & $\mathrm{Y}$ \\
\hline
\end{tabular}

The full version of the model is: $\Delta \beta_{i t}=a+b . A A A_{i t-1}+c . S i z e_{i t-1}+d . R_{-} t o_{-} T R_{i t-1}+e . B E / M E_{i t-1}+e . T D / M E_{i t-1}+\sum i . I N D_{i t}+\epsilon_{i t}$

The first group of models (restrict 1\&2) restricts the sample to cases where Size is above the median. Restrict 1 includes all control variables but no industry dummies, whilst Restrict 2 includes all control variables plus industry dummies (no-intercept). The second group of models (restrict $3 \& 4$ ) restricts the sample to cases where liquidity measure is below the median (that is, the most liquid companies). Restrict 3 includes all control variables but no industry dummies, whilst Restrict 4 includes all control variables plus industry dummies (no-intercept). First four columns are based on conventional estimation periods; the second four then repeat these for a common estimation period. $\quad \Delta \beta$ is $\mathrm{M} \beta$-W $\beta$, the difference between monthly and weekly betas. Standard errors are clustered by firm and year. $A A A$ is the Winsorised absolute value of abnormal accruals from the estimation of Modified Jones (1991) model, Size is the firm's market capitalisation as a percentage of total market capitalisation, $R \_t o \_T R$, is the Winsorised illiquidity ratio from Florackis et al. (2011), TD/ME is the gearing ratio calculated as total debt/market value of equity, and BE/ME is the book value of equity to the market value of equity. For a detailed explanation of the measures and precise descriptions of the year end dates used, see text. Industry dummies are included where indicated. $\mathrm{R}^{2}$ is the adjusted $\mathrm{R}$-Squared. For each independent variable, we show the coefficient in the first row and standard errors in the second row. $* * *, * *$ and $*$ denotes the significance at $1 \%, 5 \%$ and $10 \%$ respectively. 
Table 9: Summary statistics of size portfolio constituents, Monthly-Daily

\begin{tabular}{|c|c|c|c|c|c|}
\hline Conventional Estimation Period & \multicolumn{5}{|c|}{ Panel A: Portfolios formed on Size } \\
\hline Variable & Port $1(S)$ & Port 2 & Port 3 & Port 4 & Port $5(\mathrm{~L})$ \\
\hline Number of Firms & 806 & 797 & 789 & 796 & 787 \\
\hline Monthly Beta & $0.965 * * *$ & $1.037 * * *$ & $1.089 * * *$ & $1.046^{* * *}$ & $0.915 * * *$ \\
\hline Daily Beta & $0.520 * * *$ & $0.603 * * *$ & $0.712 * * *$ & $0.808 * * *$ & $0.895 * * *$ \\
\hline$\Delta$ Beta & $0.445 * * *$ & $0.434 * * *$ & $0.377 * * *$ & $0.238 * * *$ & 0.019 \\
\hline Size & $0.000 * * *$ & $0.000 * * *$ & $0.001 * * *$ & $0.002 * * *$ & $0.010 * * *$ \\
\hline AAA & $0.048 * * *$ & $0.047 * * *$ & $0.041 * * *$ & $0.035 * * *$ & $0.030 * * *$ \\
\hline R_to_TR & $2.628 * * *$ & $1.705 * * *$ & $1.187 * * *$ & $0.952 * * *$ & $0.569 * * *$ \\
\hline $\mathrm{TD} / \mathrm{ME}$ & $0.322 * * *$ & $0.287 * * *$ & $0.362 * * *$ & $0.394 * * *$ & $0.305 * * *$ \\
\hline $\mathrm{BE} / \mathrm{ME}$ & $0.509 * * *$ & $0.494 * * *$ & $0.472 * * *$ & $0.496^{* * *}$ & $0.430 * * *$ \\
\hline Common Estimation Period & \multicolumn{5}{|c|}{ Panel B: Portfolios formed on Size } \\
\hline Variable & Port 1 (S) & Port 2 & Port 3 & Port 4 & Port $5(\mathrm{~L})$ \\
\hline Number of Firms & 758 & 748 & 748 & 748 & 739 \\
\hline Monthly Beta & $0.964 * * *$ & $1.031 * * *$ & $1.064 * * *$ & $1.056 * * *$ & $0.938 * * *$ \\
\hline Daily Beta & $0.488 * * *$ & $0.572 * * *$ & $0.659 * * *$ & $0.809 * * *$ & $0.919 * * *$ \\
\hline$\Delta \mathrm{Beta}$ & $0.476 * * *$ & $0.458 * * *$ & $0.404 * * *$ & $0.247 * * *$ & $0.019 *$ \\
\hline Size & $0.000 * * *$ & $0.000 * * *$ & $0.001 * * *$ & $0.001 * * *$ & $0.009 * * *$ \\
\hline AAA & $0.046 * * *$ & $0.047 * * *$ & $0.043 * * *$ & $0.035 * * *$ & $0.029 * * *$ \\
\hline R_to_TR & $2.471 * * *$ & $1.785 * * *$ & $1.251 * * *$ & $0.884 * * *$ & $0.585 * * *$ \\
\hline $\mathrm{TD} / \mathrm{ME}$ & $0.320 * * *$ & $0.275 * * *$ & $0.358 * * *$ & $0.388^{* * *}$ & $0.310 * * *$ \\
\hline $\mathrm{BE} / \mathrm{ME}$ & $0.531 * * *$ & $0.487 * * *$ & $0.474 * * *$ & $0.501 * * *$ & $0.429 * * *$ \\
\hline
\end{tabular}

This table reports the summary statistics for the constituents of five equal-weighted portfolios sorted by the market capitalisation. The portfolios are formed annually. Monthly (daily) betas are estimated at the end of every calendar year using monthly (daily) returns. $A A A$ is the Winsorised absolute value of abnormal accruals from the estimation of Modified Jones (1991) model, Size is the firm's market capitalisation as a percentage of total market capitalisation, $R \_t o \_T R$, is the Winsorised illiquidity ratio from Florackis et al. (2011), TD/ME is the gearing ratio calculated as total debt/market value of equity, and $\mathrm{BE} / \mathrm{ME}$ is the book value of equity to the market value of equity. For a detailed explanation of the measures and precise descriptions of the year end dates used, see text. The sample period is 1989-2013. Port 1 (S) is the smallest size, and Port 5 (L) is the largest size portfolio. Statistical significance for beta difference, $* * * * *$ and $*$ denotes the significance at $1 \%, 5 \%$ and $10 \%$ respectively. 
Table 10: Summary statistics of size portfolio constituents, Monthly-Weekly

\begin{tabular}{|c|c|c|c|c|c|}
\hline Conventional Estimation Period & \multicolumn{5}{|c|}{ Panel A: Portfolios formed on Size } \\
\hline Variable & Port $1(\mathrm{~S})$ & Port 2 & Port 3 & Port 4 & Port $5(\mathrm{~L})$ \\
\hline Number of Firms & 808 & 793 & 795 & 793 & 786 \\
\hline Monthly Beta & $0.989 * * *$ & $1.049 * * *$ & $1.076 * * *$ & $1.051 * * *$ & $0.890 * * *$ \\
\hline Weekly Beta & $0.710 * * *$ & $0.788 * * *$ & $0.856 * * *$ & $0.919 * * *$ & $0.871 * * *$ \\
\hline$\Delta$ Beta & $0.279 * * *$ & $0.261 * * *$ & $0.219 * * *$ & $0.132 * * *$ & $0.019 *$ \\
\hline Size & $0.000 * * *$ & $0.000 * * *$ & $0.001 * * *$ & $0.002 * * *$ & $0.010 * * *$ \\
\hline AAA & $0.049 * * *$ & $0.046 * * *$ & $0.041 * * *$ & $0.035 * * *$ & $0.030 * * *$ \\
\hline R_to_TR & $2.565 * * *$ & $1.734 * * *$ & $1.216 * * *$ & $0.882 * * *$ & $0.574 * * *$ \\
\hline TD/ME & $0.332 * * *$ & $0.290 * * *$ & $0.367 * * *$ & $0.396 * * *$ & $0.297 * * *$ \\
\hline $\mathrm{BE} / \mathrm{ME}$ & $0.529 * * *$ & $0.491 * * *$ & $0.479 * * *$ & $0.508 * * *$ & $0.429 * * *$ \\
\hline Common Estimation Period & \multicolumn{5}{|c|}{ Panel B: Portfolios formed on Size } \\
\hline Variable & Port 1 (S) & Port 2 & Port 3 & Port 4 & Port $5(\mathrm{~L})$ \\
\hline Number of Firms & 758 & 746 & 749 & 747 & 741 \\
\hline Monthly Beta & $0.978 * * *$ & $1.048 * * *$ & $1.068 * * *$ & $1.052 * * *$ & $0.894 * * *$ \\
\hline Weekly Beta & $0.698 * * *$ & $0.781 * * *$ & $0.841 * * *$ & $0.921 * * *$ & $0.873 * * *$ \\
\hline$\Delta$ Beta & $0.280 * * *$ & $0.267 * * *$ & $0.227 * * *$ & $0.131 * * *$ & $0.021 * *$ \\
\hline Size & $0.000 * * *$ & $0.000 * * *$ & $0.001 * * *$ & $0.001 * * *$ & $0.009 * * *$ \\
\hline AAA & $0.046 * * *$ & $0.048 * * *$ & $0.042 * * *$ & $0.035 * * *$ & $0.029 * * *$ \\
\hline R_to_TR & $2.457 * * *$ & $1.809 * * *$ & $1.274 * * *$ & $0.874 * * *$ & $0.582 * * *$ \\
\hline $\mathrm{TD} / \mathrm{ME}$ & $0.324 * * *$ & $0.270 * * *$ & $0.345 * * *$ & $0.394 * * *$ & $0.301 * * *$ \\
\hline $\mathrm{BE} / \mathrm{ME}$ & $0.536 * * *$ & $0.489 * * *$ & $0.479 * * *$ & $0.505 * * *$ & $0.432 * * *$ \\
\hline
\end{tabular}

This table reports summary statistics for the constituents of five equal-weighted portfolios sorted by the market capitalisation. The portfolios are formed annually based on each stock's size. Monthly (weekly) betas are estimated at the end of every calendar year using monthly (weekly). AAA is the Winsorised absolute value of abnormal accruals from the estimation of Modified Jones (1991) model, Size is the firm's market capitalisation as a percentage of total market capitalisation, $R_{-} t o \_T R$, is the Winsorised illiquidity ratio from Florackis et al. (2011), TD/ME is the gearing ratio calculated as total debt/market value of equity, and BE/ME is the book value of equity to the market value of equity. For a detailed explanation of the measures and precise descriptions of the year end dates used, see text. The sample period is 1989-2013. Port 1 (S) is the smallest size, and Port 5 (L) is the largest size portfolio. Statistical significance for beta difference, $* * *, * *$ and $*$ denotes the significance at $1 \%, 5 \%$ and $10 \%$ respectively. 
Table 11: GRS Tests - Based on Size and book-to-market test portfolios

\begin{tabular}{|c|c|c|c|c|c|c|}
\hline \multirow{2}{*}{ Test Portfolios } & \multicolumn{2}{|c|}{ Monthly } & \multicolumn{2}{|c|}{ Weekly } & \multicolumn{2}{|c|}{ Daily } \\
\hline & $\alpha$ & $t$-stat & $\alpha$ & $t$-stat & $\alpha$ & $t$-stat \\
\hline S1_BM1 & -0.04 & -0.16 & -0.01 & -0.15 & 0.00 & 0.14 \\
\hline S1_BM2 & 0.04 & 0.18 & 0.01 & 0.3 & 0.01 & 0.60 \\
\hline S1_BM3 & 0.09 & 0.34 & 0.03 & 0.52 & 0.01 & 0.59 \\
\hline S2_BM1 & -0.02 & -0.07 & 0.01 & 0.19 & 0.01 & 0.51 \\
\hline S2_BM2 & 0.18 & 0.91 & 0.05 & 1.19 & 0.01 & 1.45 \\
\hline S2_BM3 & 0.11 & 0.44 & 0.04 & 0.64 & 0.01 & 0.71 \\
\hline S3_BM1 & -0.09 & -0.35 & -0.02 & -0.42 & -0.00 & -0.20 \\
\hline S3_BM2 & 0.07 & 0.37 & 0.03 & 0.62 & 0.01 & 0.85 \\
\hline S3_BM3 & 0.21 & 0.90 & 0.06 & 1.05 & 0.01 & 1.23 \\
\hline S4_BM1 & 0.14 & 0.62 & 0.03 & 0.57 & 0.01 & 0.71 \\
\hline S4_BM2 & 0.19 & 1.18 & 0.05 & 1.19 & 0.01 & 1.40 \\
\hline S4_BM3 & 0.01 & 0.06 & 0.01 & 0.22 & 0.00 & 0.17 \\
\hline S5_BM1 & 0.21 & 1.48 & 0.04 & 1.09 & 0.01 & 1.08 \\
\hline S5_BM2 & -0.00 & -0.02 & 0.00 & 0.00 & -0.00 & -0.06 \\
\hline S5_BM3 & 0.18 & 0.93 & 0.04 & 0.91 & 0.01 & 0.81 \\
\hline $\begin{array}{l}\text { GRS stat } \\
\text { GRS pval }\end{array}$ & \multicolumn{2}{|c|}{$\begin{array}{c}0.7074 \\
(0.776) \\
\end{array}$} & \multicolumn{2}{|c|}{$\begin{array}{l}0.6434 \\
(0.840)\end{array}$} & \multicolumn{2}{|c|}{$\begin{array}{c}0.6777 \\
(0.809)\end{array}$} \\
\hline$\overline{\mathbf{R}^{2}}$ & \multicolumn{2}{|c|}{0.5840} & \multicolumn{2}{|c|}{0.5437} & \multicolumn{2}{|c|}{0.5142} \\
\hline$\overline{\boldsymbol{\alpha}}$ & \multicolumn{2}{|c|}{0.09} & \multicolumn{2}{|c|}{0.03} & \multicolumn{2}{|c|}{0.01} \\
\hline Annualised $\overline{\boldsymbol{\alpha}}$ & \multicolumn{2}{|c|}{1.04} & \multicolumn{2}{|c|}{1.34} & \multicolumn{2}{|c|}{1.59} \\
\hline$|\overline{\boldsymbol{\alpha}}|$ & \multicolumn{2}{|c|}{0.11} & \multicolumn{2}{|c|}{0.03} & \multicolumn{2}{|c|}{0.01} \\
\hline$\overline{\mathbf{s e}}$ & \multicolumn{2}{|c|}{0.0021} & \multicolumn{2}{|c|}{0.0005} & \multicolumn{2}{|c|}{0.0001} \\
\hline
\end{tabular}

This table reports the results of the time series regression test (GRS test) of the valueweighted returns of $15(5 \times 3)$ intersecting Size and book-to-market $(\mathrm{BTM})$ portfolios on the asset pricing model (CAPM) at different frequencies (monthly, weekly and daily). For test portfolios S1_BM1 to S5_BM3 represents the 15 portfolios Size and book-to-market (BTM) portfolios. . We use five groups for Size (S1, S2, S3, S4 and S5) and three groups for BTM (BM1 BM2, BM3). Where S1, S2, S3, S4 and S5 are in the increasing order of size and BM1, BM2 and BM3 are in the increasing order of book-to-market ratio. For the GRS test of Gibbons, Ross and Shanken (1989), we run time series regression of the form $R_{i t}-R_{f t}=\alpha_{i}$ $+\beta_{i}\left(R_{m t}-R_{f t}\right)+\varepsilon_{i t}$ where $R_{i t}$ is the return on the test portfolio, $R_{f t}$ is the risk-free rate, $R_{m t}$ is the return on the market portfolio. We test for the rejection of the null hypothesis that all the intercept terms are jointly zero using the GRS test. The table reports the (the intercept) and its associated t-statistic for the individual portfolios. GRS stat is the GRS test statistic, GRS pval is its p-value, $\overline{R^{2}}$ is the mean adjusted R-squareds of the regressions, $\bar{\alpha}$ is the mean $\alpha,|\bar{\alpha}|$ is the mean absolute $\alpha, \overline{s e}$ is the mean standard error of the $\alpha$. The $\alpha, \bar{\alpha}$, Annualised $\bar{\alpha}$ and $|\bar{\alpha}|$ are percentages. $* * *, * *$ and $*$ denotes the significance at $1 \%, 5 \%$ and $10 \%$ significance levels respectively. The time period is from the beginning of Octorber1989 to the end of September 2013. 
Table 12: GRS Tests - Based on Standard Deviation test portfolios

\begin{tabular}{|c|c|c|c|c|c|c|}
\hline \multirow{2}{*}{ Test Portfolios } & \multicolumn{2}{|c|}{ Monthly } & \multicolumn{2}{|c|}{ Weekly } & \multicolumn{2}{|c|}{ Daily } \\
\hline & $\alpha$ & $t$-stat & $\alpha$ & $t$-stat & $\alpha$ & $t$-stat \\
\hline SD1 (Lowest) & $0.45^{* * *}$ & 2.83 & $0.08 * *$ & 2.18 & $0.01 *$ & 1.80 \\
\hline SD2 & $0.30 *$ & 1.88 & $0.07 *$ & 1.77 & $0.02 * * *$ & 2.64 \\
\hline SD3 & 0.12 & 0.65 & 0.00 & -0.01 & 0.01 & 1.11 \\
\hline SD4 & 0.18 & 1.14 & 0.03 & 0.73 & 0.01 & 0.68 \\
\hline SD5 & -0.19 & -1.11 & 0.03 & 0.59 & 0.01 & 0.90 \\
\hline SD6 & 0.04 & 0.23 & 0.04 & 0.87 & 0.01 & 0.74 \\
\hline SD7 & -0.10 & -0.51 & 0.04 & 0.85 & 0.01 & 0.68 \\
\hline SD8 & 0.14 & 0.71 & 0.03 & 0.59 & 0.01 & 1.34 \\
\hline SD9 & 0.17 & 0.77 & 0.02 & 0.43 & 0.01 & 0.83 \\
\hline SD10 & -0.32 & -1.41 & -0.05 & -0.75 & 0.00 & 0.36 \\
\hline SD11 & -0.42 & -1.55 & 0.00 & 0.04 & -0.00 & -0.30 \\
\hline SD12 (Highest) & -0.25 & -0.73 & $-0.20 * *$ & -2.54 & $-0.03 * *$ & -2.36 \\
\hline $\begin{array}{l}\text { GRS stat } \\
\text { GRS pval }\end{array}$ & \multicolumn{2}{|c|}{$\begin{array}{r}1.3862 \\
(0.171) \\
\end{array}$} & \multicolumn{2}{|c|}{$\begin{array}{r}1.2043 \\
(0.274) \\
\end{array}$} & \multicolumn{2}{|c|}{$\begin{array}{c}1.4608 \\
(0.131) \\
\end{array}$} \\
\hline$\overline{\mathbf{R}^{2}}$ & \multicolumn{2}{|c|}{0.6063} & \multicolumn{2}{|c|}{0.5685} & \multicolumn{2}{|c|}{0.5839} \\
\hline $\bar{\alpha}$ & \multicolumn{2}{|c|}{0.01} & \multicolumn{2}{|c|}{0.01} & \multicolumn{2}{|c|}{0.00} \\
\hline Annualised $\overline{\boldsymbol{\alpha}}$ & \multicolumn{2}{|c|}{0.11} & \multicolumn{2}{|c|}{0.39} & \multicolumn{2}{|c|}{1.19} \\
\hline$|\overline{\boldsymbol{\alpha}}|$ & \multicolumn{2}{|c|}{0.22} & \multicolumn{2}{|c|}{0.05} & \multicolumn{2}{|c|}{0.01} \\
\hline$\overline{\mathbf{s e}}$ & \multicolumn{2}{|c|}{0.0020} & \multicolumn{2}{|c|}{0.0005} & \multicolumn{2}{|c|}{0.0001} \\
\hline
\end{tabular}

This table reports the results of the time series regression test (GRS test) of the valueweighted returns of 12 standard deviation portfolios on the asset pricing model (CAPM) at different frequencies (monthly, weekly and daily). For test portfolios SD1-SD12, the first two characters denotes standard deviation. SD1 is the lowest standard deviation portfolio and SD12 is the largest standard deviation portfolio. For the GRS test of Gibbons, Ross and Shanken (1989), we run time series regression of the form $R_{i t}-R_{f t}=\alpha_{i}+\beta_{i}\left(R_{m t}-R_{f t}\right)+\varepsilon_{i t}$ where $R_{i t}$ is the return on the test portfolio, $R_{f t}$ is the risk-free rate, $R_{m t}$ is the return on the market portfolio. We test for the rejection of the null hypothesis that all the intercept terms are jointly zero using the GRS test. The table reports the $\alpha$ (the intercept) and its associated tstatistic for the individual portfolios. GRS stat is the GRS test statistic, GRS pval is its pvalue, $\overline{R^{2}}$ is the mean adjusted R-squareds of the regressions, $\bar{\alpha}$ is the mean $\alpha,|\bar{\alpha}|$ is the mean absolute $\alpha, \overline{s e}$ is the mean standard error of the $\alpha$. The $\alpha, \bar{\alpha}$, Annualised $\bar{\alpha}$ and $|\bar{\alpha}|$ are percentages. $* * *, * *$ and $*$ denotes the significance at $1 \%, 5 \%$ and $10 \%$ significance levels respectively. The time period is from the beginning of Octorber1989 to the end of September 2013. 
Appendix Table A1. Industry definitions

\begin{tabular}{|c|c|c|}
\hline Mnemonic & Datastream description & UK category \\
\hline BRESR & Basic Resources & BRESR \\
\hline CHMCL & Chemicals & CHMCL \\
\hline CNSTM & Construct. \& Material & CNSTM \\
\hline FDBEV & Food \& Beverage & FDBEV \\
\hline INSUN & Insurance & FINSV \\
\hline FINSV & Financial Services & FINSV \\
\hline BANKS & Banks & FINSV \\
\hline HLTHC & Healthcare & HLTHC \\
\hline INDGS & Ind. Goods \& Services & INDGS \\
\hline MEDIA & Media & MEDIA \\
\hline OILGS & Oil \& Gas & OILGS \\
\hline PERHH & Personal \& Household Goods & PERHH \\
\hline AUTOP & Automobiles \& Parts & PERHH \\
\hline RLEST & Real Estate & RLEST \\
\hline RTAIL & Retail & RTAIL \\
\hline TECNO & Technology & TECNO \\
\hline TELCM & Telecommunications & TELCM \\
\hline TRLES & Travel \& Leisure & TRLES \\
\hline UTILS & Utilities & UTILS \\
\hline
\end{tabular}

This table shows the basic Datastream Level 3 industry classifications. Merged groupings (needed to give a reasonable number of observations in each industry for the purpose of calculating the Modified Jones (1991) measure (see text for a full explanation) are shown in bold. For example, for the UK Insurance and Banks have been merged into Financial Services. Industries that are then dropped from the sample (see text) have been highlighted in grey. 